\title{
Structural changes in the shallow and transition branch of the Brewer-Dobson circulation induced by El Niño
}

\author{
Mohamadou Diallo ${ }^{1,2}$, Paul Konopka ${ }^{1}$, Michelle L. Santee ${ }^{3}$, Rolf Müller ${ }^{1}$, Mengchu Tao $^{1}$, Kaley A. Walker $^{4}$, \\ Bernard Legras $^{2}$, Martin Riese ${ }^{1}$, Manfred Ern ${ }^{1}$, and Felix Ploeger ${ }^{1,5}$ \\ ${ }^{1}$ Institute of Energy and Climate Research, Stratosphere (IEK-7), Forschungszentrum Jülich, 52425 Jülich, Germany \\ ${ }^{2}$ Laboratoire de Météorologie Dynamique, UMR8539, IPSL, UPMC/ENS/CNRS/Ecole Polytechnique, Paris, France \\ ${ }^{3}$ Jet Propulsion Laboratory, California Institute of Technology, Pasadena, California, USA \\ ${ }^{4}$ Department of Physics, University of Toronto, Toronto, Ontario, Canada \\ ${ }^{5}$ Institute for Atmospheric and Environmental Research, University of Wuppertal, Wuppertal, Germany
}

Correspondence: Mohamadou Diallo (m.diallo@fz-juelich.de)

Received: 10 July 2018 - Discussion started: 6 August 2018

Revised: 20 November 2018 - Accepted: 19 December 2018 - Published: 11 January 2019

\begin{abstract}
The stratospheric Brewer-Dobson circulation (BDC) determines the transport and atmospheric lifetime of key radiatively active trace gases and further impacts surface climate through downward coupling. Here, we quantify the variability in the lower stratospheric BDC induced by the El Niño-Southern Oscillation (ENSO), using satellite trace gas measurements and simulations with the Lagrangian chemistry transport model, CLaMS, driven by ERA-Interim and JRA-55 reanalyses. We show that despite discrepancies in the deseasonalized ozone $\left(\mathrm{O}_{3}\right)$ mixing ratios between CLaMS simulations and satellite observations, the patterns of changes in the lower stratospheric $\mathrm{O}_{3}$ anomalies induced by ENSO agree remarkably well over the 2005-2016 period. Particularly during the most recent El Niño in 2015-2016, both satellite observations and CLaMS simulations show the largest negative tropical $\mathrm{O}_{3}$ anomaly in the record. Regression analysis of different metrics of the BDC strength, including mean age of air, vertical velocity, residual circulation, and age spectrum, shows clear evidence of structural changes in the BDC in the lower stratosphere induced by El Niño, consistent with observed $\mathrm{O}_{3}$ anomalies. These structural changes during El Niño include a weakening of the transition branch of the BDC between about 370 and $420 \mathrm{~K}(\sim 100-70 \mathrm{hPa})$ and equatorward of about $60^{\circ}$ and a strengthening of the shallow branch at the same latitudes and between about 420 and $500 \mathrm{~K}(\sim 70-30 \mathrm{hPa})$. The slowdown of the transition branch is due to an upward shift in the dissipation height of the large-scale and gravity waves, while
\end{abstract}

the strengthening of the shallow branch results mainly from enhanced gravity wave breaking in the tropics-subtropics combined with enhanced planetary wave breaking at high latitudes. The strengthening of the shallow branch induces negative tropical $\mathrm{O}_{3}$ anomalies due to enhanced tropical upwelling, while the weakening of the transition branch combined with enhanced downwelling due to the strengthening shallow branch leads to positive $\mathrm{O}_{3}$ anomalies in the extratropical upper troposphere-lower stratosphere (UTLS). Our results suggest that a shift in the ENSO basic state toward more frequent El Niño-like conditions in a warmer future climate will substantially alter UTLS trace gas distributions due to these changes in the vertical structure of the stratospheric circulation.

\section{Introduction}

The lower stratosphere (10-25 km) is a key region in a changing climate. In this region, the amount of key greenhouse gases, such as water vapour and ozone, which radiatively impact temperatures both locally and globally, is regulated by advection, mixing, and chemistry (e.g. Forster and Shine, 2002, 1999; Solomon et al., 2010; Riese et al., 2012; Dessler et al., 2013). Ozone is a greenhouse gas, which is mainly produced in the stratosphere $(10-50 \mathrm{~km})$, and is directly regulated by the upwelling strength of the stratospheric circulation in the tropics. 
The stratospheric mean meridional circulation, the socalled Brewer-Dobson circulation (e.g. BDC; Brewer, 1949; Butchart, 2014), is defined as a slow circulation in which air parcels rising in the tropics drift poleward in the stratosphere and are transported downward at high latitudes via its shallow and deep branches (Bönisch et al., 2011; Lin and $\mathrm{Fu}, 2013$ ). Driven by wave breaking in the stratosphere (Haynes et al., 1991; Rosenlof and Holton, 1993; Newman and Nash, 2000; Plumb, 2002) and varying on subseasonal to decadal timescales, the BDC is modulated by natural variability (Plumb and Bell, 1982; Trepte and Hitchman, 1992; Niwano et al., 2003; Punge et al., 2009), including the El Niño-Southern Oscillation (ENSO) (Randel et al., 2009).

ENSO is a coupled atmosphere-ocean phenomenon occurring in the equatorial Pacific Ocean with drastic changes in regional sea surface temperatures (SSTs), impacting surface weather and climate (e.g. Bjerknes, 1969; Cagnazzo and Manzini, 2009; Wang et al., 2016). ENSO alternates between anomalously warm (El Niño) and cold (La Niña) conditions in the tropical eastern or central Pacific Ocean at intervals of 2-8 years (Philander, 1990; Baldwin and O'Sullivan, 1995). El Niño and La Niña events are associated with variations in tropical SSTs, convection, and atmospheric temperature as well as in the circulation throughout the global troposphere (L'Heureux et al., 2017; Scaife et al., 2017). During El Niño, the eastern equatorial or central Pacific Ocean is anomalously warm and convection is shifted towards this region (e.g. Avery et al., 2017). During La Niña, in contrast, the highest SSTs and most intense convection occur in the western Pacific. In either phase, the fluctuations associated with ENSO usually last for a little longer than 1 year. The oscillations in SSTs of the Pacific Ocean are accompanied by displacements of tropospheric temperature and precipitation patterns around the globe (Brönnimann et al., 2007).

ENSO is also a major mode of climate variability that affects the variability of the BDC. Most of the previous research on ENSO influences on the stratosphere has concentrated on tropical and extratropical temperatures as well as on planetary waves in the extratropics and on polar vortex stability during El Niño based on global circulation models and observations (e.g. Sassi et al., 2004; Manzini et al., 2006; Taguchi and Hartmann, 2006; Garcia-Herrera et al., 2006; Garfinkel and Hartmann, 2007; Calvo et al., 2008; Ineson and Scaife, 2009; Butler et al., 2014). A substantial part of the interannual variability in the lower stratosphere turns out to be related to ENSO (Randel et al., 2009; Calvo et al., 2010). El Niño events directly warm the troposphere and cool the tropical lower stratosphere with a node near the tropopause, suggesting a tropical coupling of the tropospheric and stratospheric variability (Calvo-Fernandez et al., 2004; Randel et al., 2009; Mitchell et al., 2015). Analyses of atmospheric temperatures from satellite observations indicated an overall warming of the tropical troposphere superimposed on equatorially symmetric subtropical Rossby wave gyres during El Niño events (Yulaeva and Wallace,
1994; Calvo-Fernandez et al., 2004). Using a comprehensive high-top general circulation model to investigate the dynamical mechanisms involved during ENSO winters, Simpson et al. (2011) concluded that the response in tropical upwelling is predominantly driven by anomalous transient synoptic-scale wave drag in the Southern Hemisphere subtropical lower stratosphere. Based on zonally averaged satellite observations, Randel et al. (2009) found negative ozone and temperature anomalies in the tropical lower stratosphere attributed to strengthening tropical upwelling of the BDC during El Niño events. In contrast, La Niña events induce an opposite zonal mean effect (e.g. Calvo et al., 2010; Konopka et al., 2016). Climate models show that the ENSO modulations of the tropical upwelling appear to be linked to different propagation and dissipation patterns of parameterized gravity waves during winter (Garfinkel and Hartmann, 2008; Calvo et al., 2010; Simpson et al., 2011). According to Konopka et al. (2016), the variability of tropical upwelling in the lower stratosphere shows strong regional variations in the zonally resolved picture, especially during strong La Niña years when planetary wave activity at levels directly above the tropical tropopause is enhanced and the subtropical jets are significantly disturbed.

Most previous studies of direct ENSO influence on the BDC have focused on changes in the strength of the tropical upwelling and on the mechanisms (wave-mean flow interaction) that produce its acceleration or deceleration (Randel et al., 2009; Calvo et al., 2010; Konopka et al., 2016). Here, we investigate the detailed changes in the vertical structure of different BDC branches based on satellite observations and simulations with the Chemical Lagrangian Model of the Stratosphere (CLaMS) (McKenna et al., 2002; Konopka et al., 2004; Pommrich et al., 2014). Birner and Bönisch (2011) found a separation in the residual circulation transit times (RCTT) between the shallow and deep branches of the BDC. In particular, they found much smaller transit times into the mid-latitude than into the polar lowermost stratosphere. Based on these findings, the shallow branch is found in the tropical stratosphere and in the lower mid-latitudinal stratosphere equatorward of about $60^{\circ}$ below $500 \mathrm{~K}(\sim 30 \mathrm{hPa})$, whereas the deep branch is found throughout the high-latitude stratosphere poleward of $70^{\circ}$ and above $500 \mathrm{~K}$. In addition, Lin and Fu (2013) further separated the shallow branch defined by Birner and Bönisch (2011) into two sub-branches: the transition branch (i.e. between 370 and $420 \mathrm{~K}(100-70 \mathrm{hPa}))$ and the shallow branch (i.e. between 420 and $500 \mathrm{~K}(70-30 \mathrm{hPa}))$. Here, we use this definition of the branches to identify the "fingerprints" of the ENSO-induced variability in the structure of the BDC. We disentangle the changes in each branch of the BDC related to ENSO using multiple regression analysis of different diagnostic quantities derived from the satellite observations, CLaMS simulations, and meteorology of two modern reanalysis products included in the SPARC Reanalysis Intercomparison Project (S-RIP) (Fujiwara et al., 2017). A description 
of the satellite observations, model data, and the multiple regression technique is included in Sect. 2. Section 3 shows the ENSO impact on simulated and observed ozone mixing ratios in the lower stratosphere. Section 4 presents an analysis of the ENSO-induced changes in the vertical structure of the BDC in the lower stratosphere, based on mean age of air, vertical velocity, residual circulation, and age spectrum diagnostics. Finally, we discuss a possible dynamical mechanism for these changes in the vertical structure of the circulation and potential impacts on decadal and long-term changes (Sect. 5).

\section{Data and methodology}

\subsection{Description of the CLaMS model}

The Chemical Lagrangian Model of the Stratosphere (CLaMS) is a Lagrangian transport model with trace gas transport based on the motion of 3-D forward trajectories and an additional parameterization of subgrid-scale atmospheric mixing (McKenna et al., 2002; Konopka et al., 2004). The CLaMS model allows ozone concentrations to be simulated through a simplified formulation of stratospheric chemistry (Pommrich et al., 2014). The lower boundary values for the ozone mixing ratio are set to zero in the lowest model layer (roughly the boundary layer), while the upper boundary condition $(\sim 500 \mathrm{~K})$ is imposed based on mean climatological satellite fields. For this study, we carried out simulations with the CLaMS model driven by 6-hourly horizontal winds and diabatic heating rates both from ERA-Interim (ERA-I) (Dee et al., 2011) and Japanese 55-year Reanalysis (JRA-55) (Kobayashi et al., 2015) reanalyses, respectively provided by the European Centre for Medium-Range Weather Forecasts and the Japan Meteorological Agency. For the wind and temperature fields, CLaMS uses $1^{\circ} \times 1^{\circ}$ for the horizontal resolution and the native reanalysis vertical resolution. The mean vertical resolution of air parcels in the CLaMS Lagrangian model is about $400 \mathrm{~m}$ near the tropopause. The simulation driven by ERA-I covers the 1979-2016 period, whereas the simulation driven by JRA-55 covers the 1979-2013 period. Both reanalyses are described in detail by Fujiwara et al. (2017) for the S-RIP project, which is a coordinated intercomparison of modern global atmospheric reanalyses.

\subsection{Lower stratospheric $\mathrm{O}_{3}$ from CLaMS and Aura-MLS}

To analyse the response of the BDC to ENSO variability, we use ozone $\left(\mathrm{O}_{3}\right)$ mixing ratios and different diagnostics of the stratospheric circulation strength, as described in the following. The simulated $\mathrm{O}_{3}$ mixing ratios from the CLaMS setup used in this work were previously analysed by Pommrich et al. (2014) for validation of the CLaMS simulations. In addition, the $\mathrm{O}_{3}$ mixing ratios from CLaMS simulations driven by ERA-I and JRA-55 are sampled at the MLS measure- ment geolocations to avoid sampling bias during the intercomparisons. Reliable agreement with satellite observations has been found regarding seasonality as well as variability related to the Quasi-Biennial Oscillation (QBO). The first part of the present analysis is a further validation of CLaMS' ability to reproduce interannual stratospheric variability related to ENSO.

The observational data used for comparison with CLaMS simulations are monthly mean $\mathrm{O}_{3}$ mixing ratios in the lower stratosphere from the Aura Microwave Limb Sounder (MLS), covering the period 2005-2016 (Livesey et al., 2017). The MLS instrument, flying aboard the EOS-Aura satellite, is designed to measure a wide range of physical and chemical quantities, including $\mathrm{O}_{3}$ (Waters et al., 2006). The version 4.2 abundances MLS data were produced with improved retrieval algorithms, which substantially reduced the occurrence of unrealistically small $\mathrm{O}_{3}$ values at $215 \mathrm{hPa}$ in the tropics observed in the previous version 2.2 MLS product (Livesey et al., 2008). Note that the version 4.2 $\mathrm{MLS} \mathrm{O}_{3}$ data used here are not significantly different from the previous version MLS observations at pressures less than $100 \mathrm{hPa}$, but show less oscillatory behaviour and fewer retrieval artifacts induced by cloud contamination in the tropical upper troposphere and lower stratosphere. The version $4.2 \mathrm{O}_{3}$ data are characterized by a vertical resolution of $2.5-3.5 \mathrm{~km}$, a precision of $\pm 0.02-0.04 \mathrm{ppmv}$, a systematic uncertainty of $\pm 0.02-0.05 \mathrm{ppmv}+ \pm 5-10 \%$, and a lowest recommended level of $261 \mathrm{hPa}$ for individual profile measurements with a horizontal resolution in the UTLS of $\sim 300-400 \mathrm{~km}$ along the orbital-track line of sight (Livesey et al., 2017; Santee et al., 2017). The regression results will not be affected by these intrinsic uncertainties since they apply to the $\mathrm{O}_{3}$ mixing ratios and not the anomalies. Additional detailed information on the quality of $\mathrm{MLS} \mathrm{O}_{3}$ in the upper tropospherestratosphere in previous versions can be found in dedicated validation papers (Read et al., 2007; Livesey et al., 2008; Froidevaux et al., 2008).

\subsection{Metrics of the BDC}

In addition to the trace gas diagnostics, the strength of the $\mathrm{BDC}$ is commonly deduced from age of air related diagnostics, including the mean age of air (AoA) and the age spectrum, and also the residual vertical velocity $\left(\overline{w^{*}}\right)$, the residual circulation transit time (RCTT), and the residual circulation mass stream function $\left(\psi^{*}\right)$ (Reithmeier et al., 2008; Li et al., 2012; Diallo et al., 2012; Butchart, 2014; Abalos et al., 2015; Ploeger et al., 2015a, b; Ploeger and Birner, 2016). Mean AoA is defined as the average transit time for an air parcel since entering the stratosphere, and is therefore the first moment of the full transit time distribution termed the age spectrum. As shown by Hall and Plumb (1994), mean AoA can be calculated in a model from a "clock tracer" that is an inert tracer with a linear increase in the troposphere or at the surface. Note that we calculate mean AoA and age spectrum 
relative to the lowest model level following the surface, as this is a common choice in global models (Waugh and Hall, 2002).

The age spectrum includes the detailed transit time information and is advantageous for investigating different transport pathways (e.g. Ploeger and Birner, 2016). In the CLaMS model, the age spectrum is calculated using a total of 60 different boundary pulse tracers, with pulses released in the lowest model layer in the tropics between $15^{\circ} \mathrm{S}$ and $15^{\circ} \mathrm{N}$, constituting the pulse source region $\Omega$ at source times $t^{\prime}$. Note that releasing the pulses only in the tropics between $15^{\circ} \mathrm{S}$ and $15^{\circ} \mathrm{N}$ might bias the age spectrum results in the lowermost stratosphere. It is likely that a substantial amount of air originating in the extratropics crosses the tropopause near the subtropical jets, especially during summer and autumn in the Northern Hemisphere. Since this air is not taken into account, the young portion of the age spectrum is likely being underestimated. For each pulse, the tracer mixing ratio $\chi_{i}(r, t)$ is set to unity in $\Omega$ for 30 days, and is set to zero in $\Omega$ otherwise. These pulses are released every 2 months. For instance, the first tracer pulse has its source time in January 1979, the second tracer pulse in March 1979, and so on. The age spectrum is Green's function or a boundary propagator, $G$, that solves the continuity equation for the mixing ratio of a conserved and passive tracer (Hall and Plumb, 1994). As a function of transit time (elapsed time) $\tau=t-t_{i}^{\prime}$, the age spectrum is constructed from these $N$ pulse tracers at each sample field time $t$ and sample region $r$ as $G\left(r, t \mid \Omega, t-\tau_{i}\right)=\chi_{i}(r, t)$. For more details about the set-up and calculations, see Ploeger and Birner (2016).

The residual circulation transit time (RCTT) is a 2-D diagnostic defined as the transit time of an air parcel through the stratosphere, if it were advected only by the residual circulation, and measures the strength of the residual circulation (Bönisch et al., 2011; Birner and Bönisch, 2011). RCTTs are calculated from 2-D CLaMS backward trajectories driven by the mass-weighted isentropic zonal mean diabatic circulation, and the reference level is set to the $340 \mathrm{~K}$ isentrope in the tropics to include transport in the tropical tropopause layer (Fueglistaler et al., 2009a). For more details about the RCTT calculations see Ploeger et al. (2015a). In addition, we analyse the strength of the tropical upwelling related to ENSO using $\overline{w^{*}}$, calculated from the transformed Eulerian mean (TEM) circulation standard formula in geometric coordinates (e.g. Eq. 3.5, Andrews et al., 1987) and the diabatic heating rate (Fueglistaler et al., 2009b; Wright and Fueglistaler, 2013) from both reanalyses. In contrast to the integrated residual circulation transit time along the trajectory of an air parcel, $\overline{w^{*}}$ is a local 2-D quantity.

\subsection{Multiple regression model}

To properly disentangle the ENSO impact on these metrics of the BDC from the other sources of natural variability, the monthly zonal mean $\mathrm{O}_{3}$ mixing ratios and other diag- nostic quantities are analysed by using a multiple regression model as a function of latitude $(\phi)$ and altitude $(z)$. This regression method is an established method and appropriate to disentangle the relative influences of the considered climate indices on BDC variability, as it includes time-lag coefficients as a function of $\phi$ and $z$ for each proxy, including the ENSO signal. For more details about the method and its further applications, see Diallo et al. (2012, 2017, 2018). The regression method decomposes the temporal evolution of a monthly zonal mean parameter, $\chi$, in terms of a long-term linear trend, seasonal cycle, QBO, ENSO, volcanic aerosol, and a residual. The model yields for a given parameter, $\chi$ (herein $\mathrm{O}_{3}, \mathrm{AoA}, \overline{w^{*}}, \mathrm{RCTT}, \Psi$, age spectrum, air mass fraction, temperature, zonal mean wind, Eliassen-Palm flux, and its divergence),

$$
\begin{aligned}
& \chi(t, \phi, z)=a(\phi, z) \cdot t+C(t, \phi, z)+\sum_{k=1}^{3} b_{k}(\phi, z) \\
& \cdot P_{k}\left(t-\tau_{k}(\phi, z)\right)+\epsilon(t, \phi, z),
\end{aligned}
$$

where $P_{k}$ represents the predictors or proxies of different atmospheric sources of variability. Thus, $P_{1}$ is a normalized QBO index (QBOi) from CDAS/Reanalysis zonally averaged winds at $50 \mathrm{hPa}, P_{2}$ is the normalized Multivariate ENSO Index (MEI) (Wolter and Timlin, 2011) and $P_{3}$ is the Aerosol Optical Depth (AOD) from satellite data (Vernier et al., 2011; Khaykin et al., 2017; Thomason et al., 2018). The coefficients are a linear trend $a$, the annual cycle $C(t, \phi, z)$, the amplitude $b_{1}$ and the lag $\tau_{1}(\phi, z)$ associated with the QBO, the amplitude $b_{2}$ and the lag $\tau_{2}(\phi, z)$ associated with ENSO and the amplitude $b_{3}$ and the lag $\tau_{3}(\phi, z)$ associated with AOD. The constraint applied to determine the parameters $a, b_{1}, b_{2}, b_{3}, \tau_{1}(\phi, z), \tau_{2}(\phi, z), \tau_{3}(\phi, z)$ and $C$ is to minimize the residual $\epsilon(t, \phi, z)$ in the least squares sense. Because of the presence of lags in the QBO, ENSO and AOD terms in Eq. (1), the problem is nonlinear and the residual may have multiple minima as a function of the parameters. In order to determine the optimal values of $\tau_{1}(\phi, z), \tau_{2}(\phi, z)$ and $\tau_{3}(\phi, z)$, the residual is first minimized at fixed lag and then sorted out over a range of lags. This is done in sequence for QBO, ENSO and AOD. Here we neglect solar forcing, because our data set covers only one solar period. Uncertainty estimates for the statistical fits are calculated using a Student's t-test technique (Zwiers and von Storch, 1995; Bence, 1995; von Storch and Zwiers, 1999).

\section{ENSO impact on lower stratospheric $\mathrm{O}_{3}$}

Figure 1a shows the interannual variability of the deseasonalized $\mathrm{O}_{3}$ from CLaMS simulations driven by ERA-I and JRA-55 sampled at the MLS measurement geolocations together with MLS observations averaged in the tropical lower stratosphere between 380 and $425 \mathrm{~K}$ as a percentage change relative to the climatological monthly mean mixing ratio dur- 

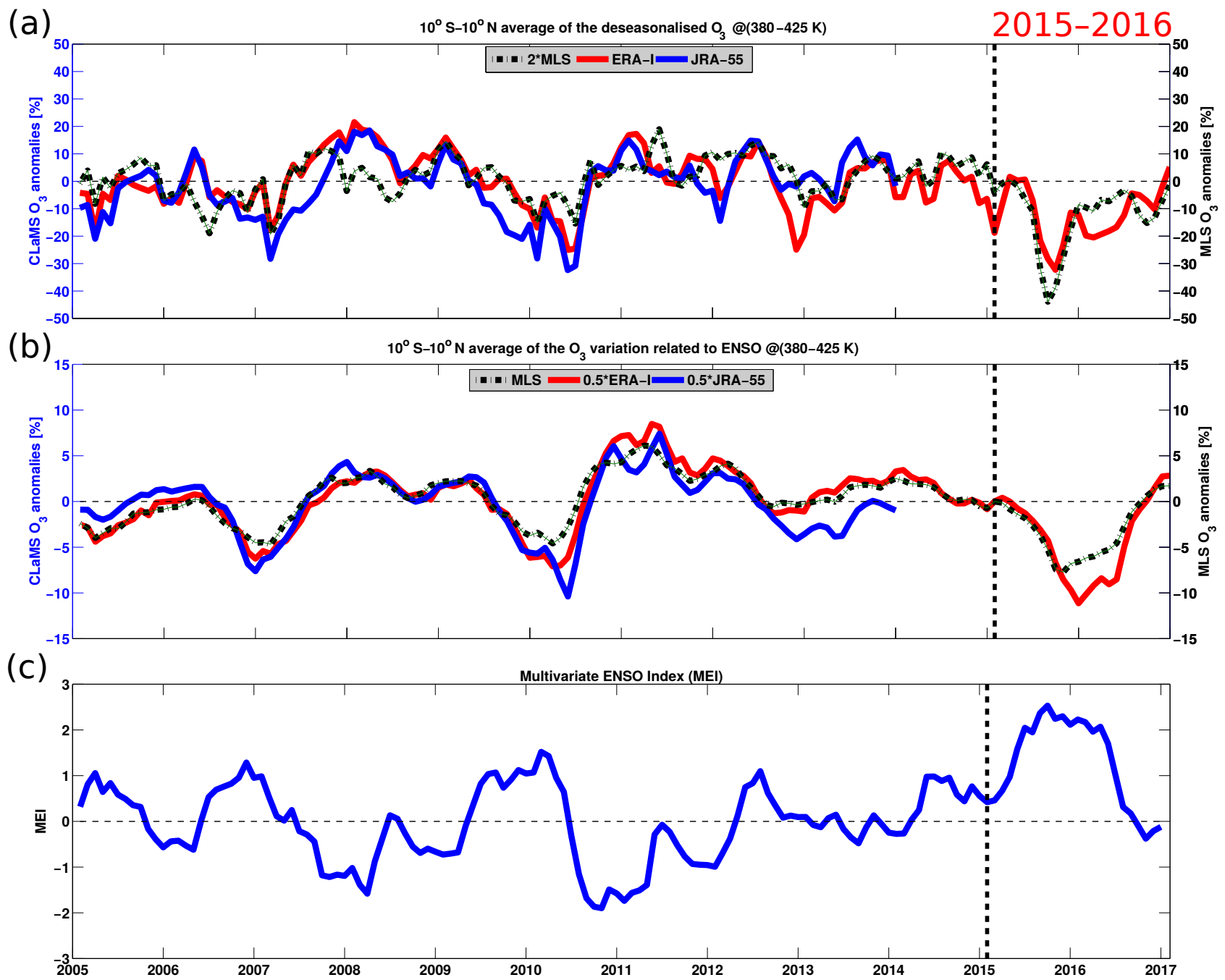

Figure 1. Time evolution of the tropical $\mathrm{O}_{3}$ anomalies from CLaMS simulations sampled at the MLS measurement geolocations together with MLS satellite observations in percent change from the monthly zonal mean climatology and averaged between 380 and $425 \mathrm{~K}$ for the 2005-2016 period. Panel (a) shows the $10^{\circ} \mathrm{S}-10^{\circ} \mathrm{N}$ deseasonalized $\mathrm{O}_{3}$ for CLaMS driven by ERA-I (red); CLaMS driven by JRA-55 (blue) and MLS (dashed black). Panel (b) shows the ENSO-induced $\mathrm{O}_{3}$ anomalies in the tropics for CLaMS driven by ERA-I (red); CLaMS driven by JRA-55 (blue) and MLS (dashed black) derived from the multiple regression fit. Panel (c) shows the Multivariate ENSO Index (MEI: blue). Note that there is a factor of 2 difference in the legend in (a) and (b), reflecting the difference in the magnitude of the deseasonalized $\mathrm{O}_{3}$ mixing ratio between CLaMS and MLS. Vertical black dashed line indicates February 2015 for the warm ENSO onset.

ing the 2005-2016 period. Generally, a consistent picture of $\mathrm{O}_{3}$ interannual variability emerges between observations and model simulations driven by ERA-I and JRA-55. Note that the $\mathrm{CLaMS} \mathrm{O}_{3}$ values are 2 times as large as the MLS $\mathrm{O}_{3}$ values, and this difference in the magnitude of the $\mathrm{O}_{3}$ anomalies is not due to a sampling bias. The factor of 2 difference in the zonal mean magnitude between CLaMS and MLS $\mathrm{O}_{3}$ anomalies is likely due to the lack of tropospheric $\mathrm{O}_{3}$ chemistry and the $\mathrm{O}_{3}$ lower boundary condition being set to zero in CLaMS, combined with tropical upwelling being too strong and tropical-extratropical exchange being too weak in the model. These different possible reasons for the factor of 2 difference are further discussed in Sect. 5. The desea- sonalized tropical $\mathrm{O}_{3}$ time series exhibit seasonal variations in both model simulations and observations, which are negatively correlated with the Multivariate ENSO Index (MEI) (Fig. 1a, c). In particular, during the 2015-2016 period, the deseasonalized $\mathrm{O}_{3}$ shows negative anomalies in the tropical lower stratosphere due to the enhanced tropical upwelling caused by both the extreme El Niño event and the QBO disruption (e.g. easterly wind shear at $100-40 \mathrm{hPa}$ ) (Diallo et al., 2018).

However, the overall $\mathrm{O}_{3}$ interannual variability is challenging to interpret because of its regulation by the complex interplay between the ENSO- and QBO-induced variability (e.g. Taguchi, 2010; Liess and Geller, 2012; Neu et al., 
2014; Diallo et al., 2018), by the climate change impact (e.g. Bekki et al., 2013; Iglesias-Suarez et al., 2018; Ball et al., 2018; Wargan et al., 2018), and by the emissions of ozone depletion substances (e.g. Dhomse et al., 2018; Chipperfield et al., 2018; Montzka et al., 2018). Therefore, to elucidate the ENSO impact on the stratospheric $\mathrm{O}_{3}$ anomalies, the multiple regression is performed both without and with explicit inclusion of the ENSO signal. The difference between the residual ( $\epsilon$ in Eq. 1) without and with explicit inclusion of the ENSO signal gives the ENSO-induced impact on stratospheric $\mathrm{O}_{3}$ anomalies. This approach of differencing the residuals is similar to direct calculations, projecting the regression fits onto the ENSO basis functions herein termed the amplitude variation $\left(b_{2} \times \mathrm{SD}(\mathrm{MEI})\right.$, i.e. term $b_{2}$ in (1) normalized by the standard deviation of the MEI). For illustration, please see supplementary Figs. 2 and 4 in Diallo et al. (2017) and also Diallo et al. (2018).

Figure $1 \mathrm{~b}$ shows time series of the $\mathrm{O}_{3}$ changes induced by ENSO variability in the tropical lower stratosphere averaged between 380 and $425 \mathrm{~K}$ and estimated from the difference between the residual ( $\epsilon$ in Eq. 1) with and without explicit inclusion of the ENSO signal for the 2005-2016 period. The ENSO-induced variability in lower stratospheric $\mathrm{O}_{3}$ mixing ratios shows a good agreement between CLaMS simulations driven by both reanalyses and MLS observations, though again with a factor of 2 difference in the magnitude. These $\mathrm{O}_{3}$ anomalies show a strong negative correlation with the MEI, reaching $-77.9 \%$ for CLaMS driven by ERA-I, $-70 \%$ for CLaMS driven by JRA-55, and $-85.7 \%$ for MLS.

Figure 2a-c show latitude-time series of the ENSOinduced variability in monthly mean $\mathrm{O}_{3}$ mixing ratios in the lower stratosphere and estimated from the difference between the residual ( $\epsilon$ in Eq. 1) with and without explicit inclusion of the ENSO signal for the 2005-2016 period. The patterns of ENSO-induced variability in the CLaMS $\mathrm{O}_{3}$ driven by both reanalyses and MLS observations agree very well, though again with a factor of 2 difference in the magnitude related to the high-biased $\mathrm{O}_{3}$ variability in CLaMS consistent with Fig. 1a, b. In addition, the gradient in the MLS and JRA-55 $\mathrm{O}_{3}$ anomalies between the tropics and extratropics in the Southern Hemisphere is smoother than that in CLaMS simulations driven by ERA-I, likely due to its too strong tropical upwelling (Dee et al., 2011; Wright and Fueglistaler, 2013; Abalos et al., 2015). The CLaMS and MLS $\mathrm{O}_{3}$ anomalies are negative in the lower stratosphere during El Niño years (e.g. 2006-2007, 2010-2011, 20152016) and positive during La Niña years (e.g. 2008-2009, 2011-2012, 2013-2014), consistent with previous studies (Randel et al., 2009; Calvo et al., 2010; Konopka et al., 2016). In particular, the most recent El Niño event produces an extremely large negative $\mathrm{O}_{3}$ anomaly in the lower stratosphere, inducing a record anomaly of $-15 \%$ in the tropics for MLS (twice as large for CLaMS), consistent with Diallo et al. (2018). This strong increase in the magnitude of negative $\mathrm{O}_{3}$ anomalies is interpreted as a manifestation of the strengthening of the tropical upwelling induced by El Niño (see Sect. 4) (Randel et al., 2009). These substantial $\mathrm{O}_{3}$ anomalies are consistent with recently published strong ozone and water vapour anomalies during the 2015-2016 El Niño (Avery et al., 2017; Diallo et al., 2018). The two consecutive La Niña events in 2011-2012 exhibit the largest positive $\mathrm{O}_{3}$ anomalies in decadal satellite records.

Figure 3a-c depict the zonal mean impact of ENSO on $\mathrm{O}_{3}$ variability for CLaMS simulations driven by ERA-I (a) and JRA-55 (b) together with MLS (c) calculated as the projection of the regression fits onto the ENSO basis functions for the 2005-2016 period, i.e. the amplitude variation. There is good agreement between CLaMS and MLS regarding the pattern of $\mathrm{O}_{3}$ variations related to El Niño-like conditions, with the negative $\mathrm{O}_{3}$ anomalies in the JRA-55 simulations much more confined to the tropics. In the tropical UTLS, the negative $\mathrm{O}_{3}$ anomalies during El Niño are due to the enhanced tropical upwelling, transporting upward fresh air poor in $\mathrm{O}_{3}$ from the troposphere. The negative $\mathrm{O}_{3}$ anomalies from simulations driven by ERA-I are stronger than those from MLS and JRA-55, corroborating the too strong upwelling in ERA-I (Dee et al., 2011; Schoeberl et al., 2012). In the extratropical UTLS $\left(30-70^{\circ}\right)$, CLaMS simulations driven by both reanalyses together with MLS observations show a related positive $\mathrm{O}_{3}$ anomaly due to enhanced downwelling and consistent with recent studies (Neu et al., 2014; Banerjee et al., 2016; Meul et al., 2018). In addition, the positive $\mathrm{O}_{3}$ anomalies induced by the ENSO signal in the extratropics indicate hemispheric asymmetry in both simulations and observations, with a generally weaker response in the Southern Hemisphere than in the Northern Hemisphere (Fig. 3ac). This hemispheric asymmetry results from a weak quasihorizontal mixing between tropics and extratropics induced by the asymmetry in the wave breaking response to El Niñolike conditions, which will be discussed further in Sect. 5. The negative $\mathrm{O}_{3}$ anomalies seen in the Southern Hemisphere polar region reflect the large variability at high latitudes in Antarctic ozone due to chemical O 3 loss (Solomon, 1999; Laube et al., 2014; WMO, 2014; Montzka et al., 2018). Note that the absence of $\mathrm{O}_{3}$ anomalies above $500 \mathrm{~K}$ in CLaMS (Fig. 3a) results from the upper boundary condition, which is imposed above this level based on mean climatological fields and thus precludes representation of variability.

Despite generally good agreement between simulations and observations, the signal in the MLS data is weaker in both the tropics and the extratropics, particularly in the Southern Hemisphere. The stratospheric entry value of fire emission markers is strongly enhanced under El Niño conditions (Fromm and Servranckx, 2003; Fromm et al., 2006; Trentmann et al., 2006). Increased upper tropospheric $\mathrm{O}_{3}$ mixing ratios have also been linked to increased $\mathrm{O}_{3}$ precursor emissions from biomass burning. The dynamical changes, severe drought, and ensuing large-scale forest fires in Indonesia and Malaysia induced by strong El Niño events have been conclusively associated with substantial anoma- 

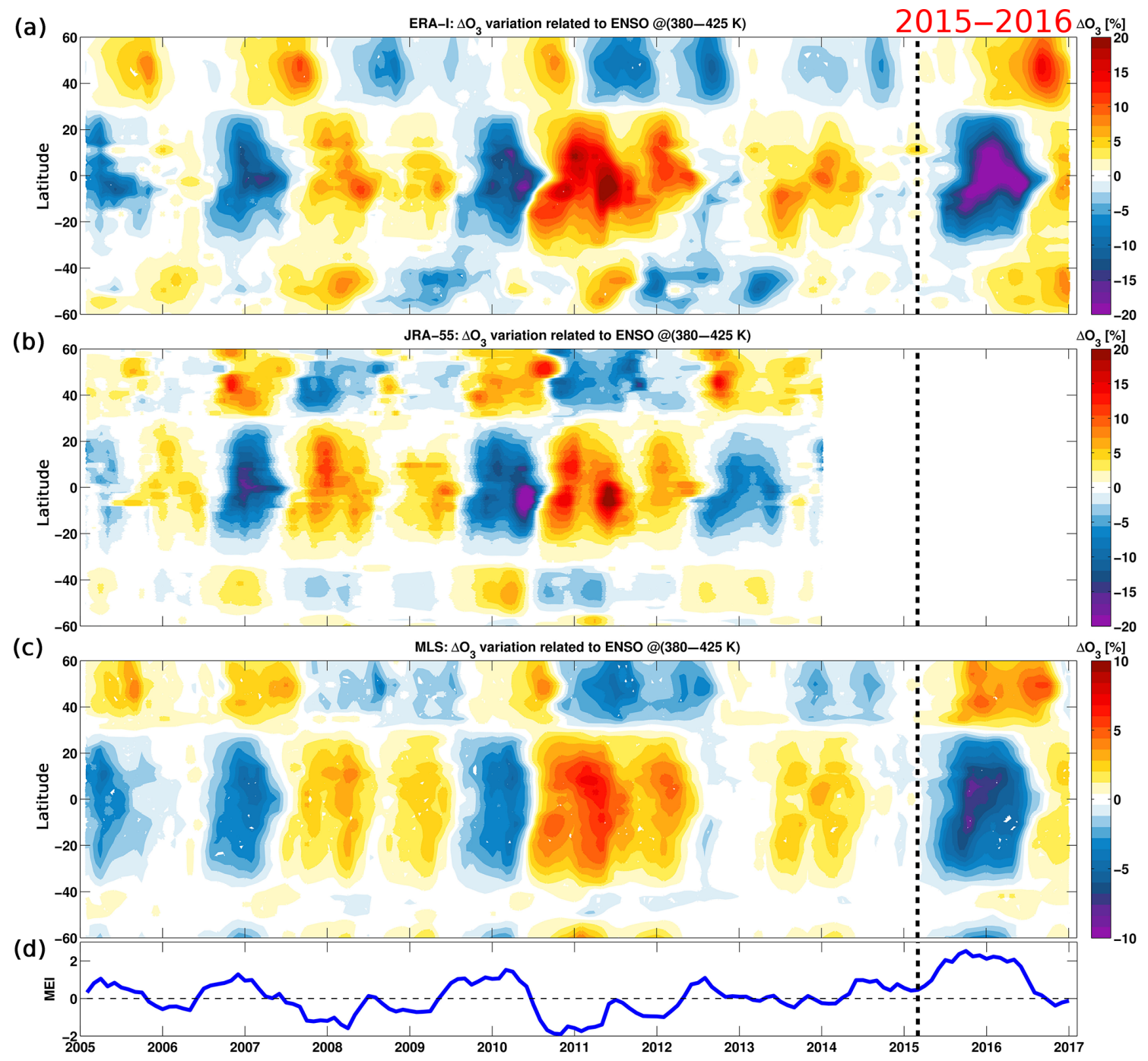

Figure 2. Latitude-time evolution of the ENSO impact on lower stratospheric $\mathrm{O}_{3}$ from (a) CLaMS simulations driven by ERA-I; (b) CLaMS simulations driven by JRA-55 and (c) MLS satellite observations in percent change from the monthly zonal mean climatology derived from the multiple regression fit and averaged between 380 and $425 \mathrm{~K}$ for the $2005-2016$ period. Note that there is a factor of 2 difference in the colour scales in (a), (b), and (c), reflecting the difference in the magnitude of the deseasonalized $\mathrm{O}_{3}$ mixing ratio between CLaMS and MLS. Panel (d) shows the MEI in blue. Vertical black dashed line indicates February 2015 for the warm ENSO onset.

lies in UTLS CO and $\mathrm{O}_{3}$ (e.g. Thompson et al., 2001; Logan et al., 2008; Chandra et al., 2007, 2009; Nassar et al., 2009; Livesey et al., 2013; Field et al., 2016). Thus, tropical upper tropospheric $\mathrm{O}_{3}$ mixing ratios may be enhanced not only because of increased convective transport, but also increased fire emissions (this was especially true in 2015, Field et al., 2016). Hence, the tropical UTLS $\mathrm{O}_{3}$ mixing ratios will reflect the net change from competing effects that CLaMS simulations cannot capture because of the use of zero $\mathrm{O}_{3}$ as a lower boundary condition, as mentioned earlier. In some cases these local/regional effects may have been large enough to impact the tropical mean $\mathrm{O}_{3}$ mixing ratios. In the CLaMS model this chemical relationship between $\mathrm{CO}$ and $\mathrm{O}_{3}$ is missing, which might explain the discrepancies with MLS observations.

\section{Structural changes in the lower stratospheric BDC}

In this section, various diagnostics of the BDC strength (e.g. AoA, $\overline{w^{*}}, \Psi$, RCTT, age spectrum) from simulations with CLaMS, driven by ERA-I and JRA-55 reanalyses, are analysed for ENSO-related variability and consistency with the $\mathrm{O}_{3}$-based results (see Sect. 3). In contrast to the complex chemistry in trace gases, the AoA is particularly useful as a diagnostic for investigating variability in stratospheric transport and mixing, as it is not influenced by chemistry. 
(a)

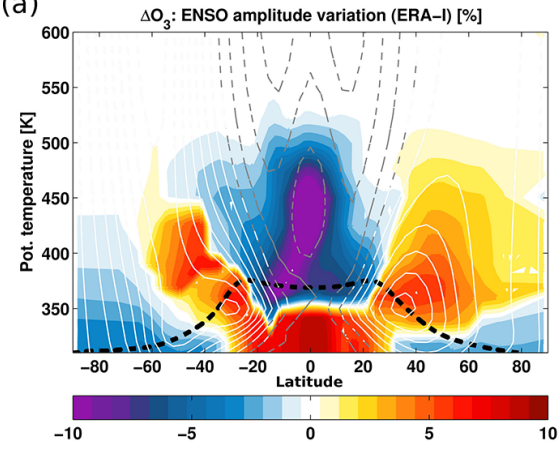

(b)

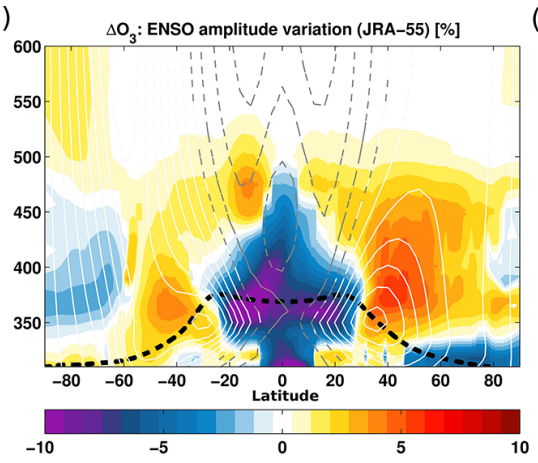

(c)

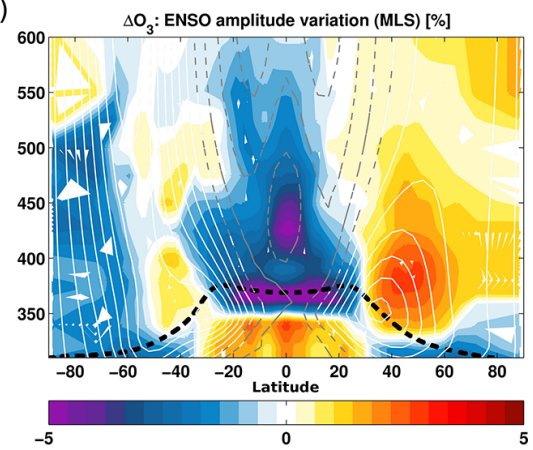

Figure 3. Zonal mean distribution of the ENSO impact on stratospheric $\mathrm{O}_{3}$ variability from (a) CLaMS simulations driven by ERA-I; (b) CLaMS simulations driven by JRA-55 and (c) MLS satellite observations in percent change relative to the climatological monthly mean mixing ratios. The amplitude of the $\mathrm{O}_{3}$ variations (term $b_{2} \times \mathrm{SD}(\mathrm{MEI})$ ) attributed to ENSO is calculated by projecting the regression fits onto the ENSO basis functions for the 2005-2016 period. Note that there is a factor of 2 difference in the colour scales in (a), (b), and (c), reflecting the difference in the magnitude of the $\mathrm{O}_{3}$ changes between CLaMS and MLS. Black dashed horizontal line indicates the climatological tropopause from ERA-I (a, b) and JRA-55 c). Zonal mean wind component $u\left(\mathrm{~m} \mathrm{~s}^{-1}\right.$ ), averaged over the $2005-2016$ period, from ERA-I is overplotted as solid white (westerly) and dashed grey (easterly) lines.

Figure $4 \mathrm{a}-\mathrm{b}$ show the amplitude variation of the ENSO impact on AoA for the 1979-2013 period. The vertical structure of AoA anomalies depicts a pattern of changes similar to the ENSO imprint on $\mathrm{O}_{3}$ mixing ratios. Negative AoA anomalies (young AoA) emerge throughout the tropics in both ERAI and JRA-55 reanalyses and propagate upwards into the stratosphere during El Niño-like conditions. Positive AoA anomalies (old AoA) arise in the extratropics with a strong effect in the Northern Hemisphere during El Niño, leading to hemispheric asymmetry consistent with the $\mathrm{O}_{3}$ anomalies. The picture of AoA anomalies agrees well with $\mathrm{O}_{3}$ anomalies from CLaMS simulations and MLS observations, albeit with a smoother pattern of changes for MLS $\mathrm{O}_{3}$ anomalies in the Southern Hemisphere lower stratosphere (Fig. 3).

Figure $4 \mathrm{c}, \mathrm{d}$ depict the ENSO-induced variability in the $\overline{w^{*}}$, indicating a clear increase in the tropical upwelling during El Niño-like conditions, consistent with recent findings (Randel et al., 2009; Calvo et al., 2010; Konopka et al., 2016). The vertical structure of $\mathrm{AoA}$ and $\mathrm{O}_{3}$ changes in the UTLS, i.e. negative anomalies in the tropics and positive anomalies in the extratropics during El Niño-like conditions, is mainly explained by the ENSO-induced anomalies in $\overline{w^{*}}$ and in the diabatic heating rate $(\dot{\Theta})$ (Fig. 4c-f). During El Niño, the increase in the ascending branch of the BDC (positive tropical $\overline{w^{*}}$ and $\dot{\Theta}$ ) anomalies enhances upward transport of young tropospheric air poor in $\mathrm{O}_{3}$ into the tropical stratosphere. The enhanced downwelling in the mid and high latitudes transports more old stratospheric air rich in $\mathrm{O}_{3}$ downwards into the polar regions (see Fig. 3), contrasting with model projections of shorter stratospheric residence time due to enhanced downwelling in a warming climate (e.g. McLandress and Shepherd, 2009; Lin and Fu, 2013; Butchart, 2014; Hardiman et al., 2014). The main difference in the response of the AoA to El Niño compared to its global warming re- sponse lies in the difference in the transition branch response and the difference in timescale of the El Niño perturbations compared to those induced by a globally warming climate, which is of the order of years. In a warming climate, climate models predict a globally decreasing AoA due to faster upwelling and downwelling of all branches (transition, shallow, and deep) over a timescale of decades, leading to a shorter stratospheric residence time of air parcels tropically ascending. In contrast, during El Niño, the shallow and transition branches evolve in different regimes, i.e. a weakening transition branch, a strengthening shallow branch, and an unclear response for the deep branch. El Niño strengthening the downwelling of the shallow branch has a typical timescale of a few months and maximizes in winter, transporting much older air downward to the lower extratropical stratosphere and hence increasing AoA. The El Niño effect is analogous to the effect of seasonality, where stronger winter downwelling is also related to increasing AoA in the extratropical lower stratosphere. Consequently, during El Niño the enhanced tropical upwelling depletes $\mathrm{O}_{3}$ in the tropical lower stratosphere, while the strengthened downwelling of the shallow branch enhances $\mathrm{O}_{3}$ in the mid and high latitudes. Opposite changes occur during La Niña (not shown). The ENSO-induced variations in $\overline{w^{*}}$ and $\dot{\Theta}$ agree well in the two reanalyses in terms of morphology, though not in magnitude (see Fig. $4 \mathrm{c}-\mathrm{f}$ ). The $\overline{w^{*}}$ and $\dot{\Theta}$ changes related to $\mathrm{El}$ Niño for JRA-55 are more confined in the tropics and exhibit stronger downwelling in the Northern Hemisphere than those from ERA-I. The latter also exhibits stronger $\overline{w^{*}}$ anomalies in the tropics than JRA-55, consistent with the differences between the two reanalyses in $\mathrm{O}_{3}$ anomalies (Fig. 3).

However, as the AoA is affected by both residual circulation and mixing processes (e.g. Garny et al., 2014; Ploeger et al., 2015b, a), there could be an ambiguous relation be- 
(a)

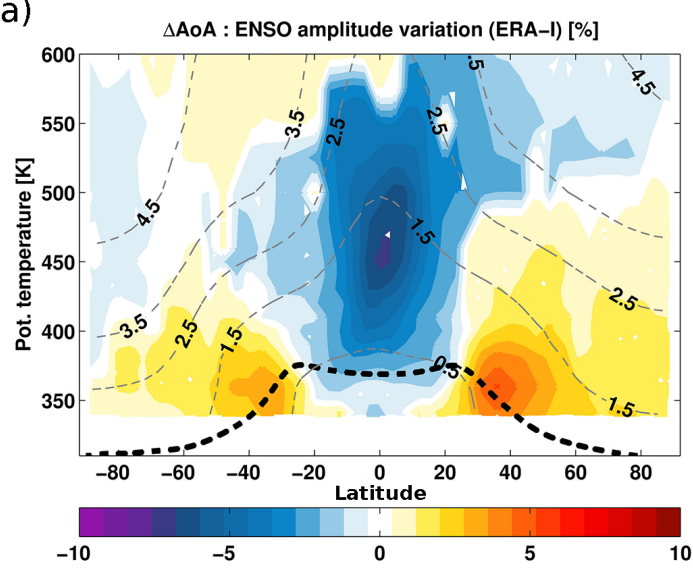

(b)

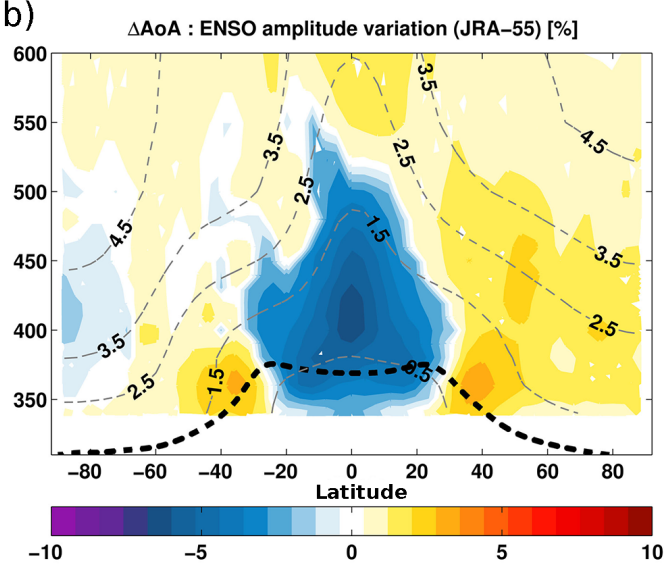

(c)

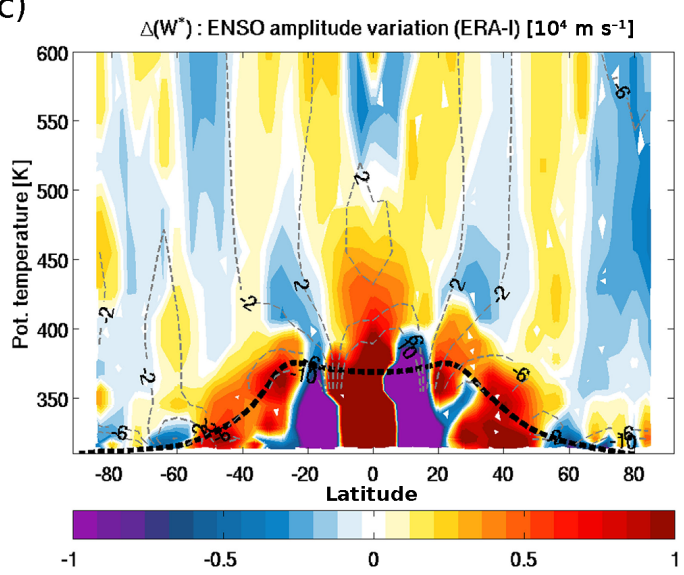

(e)

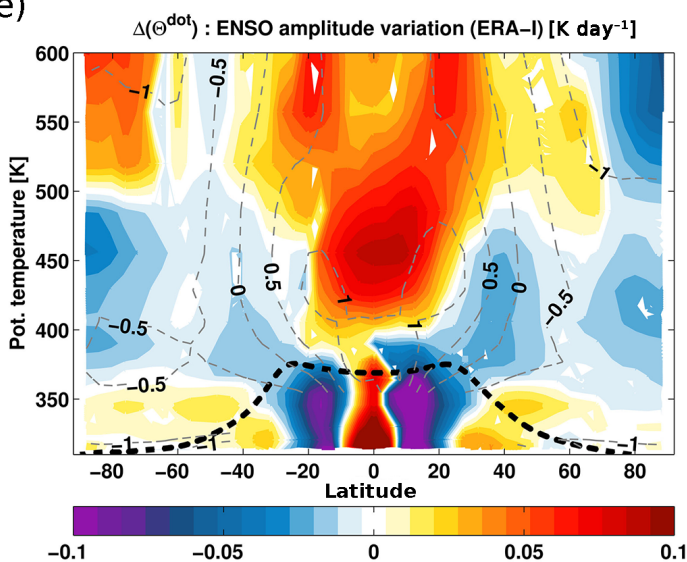

(d)

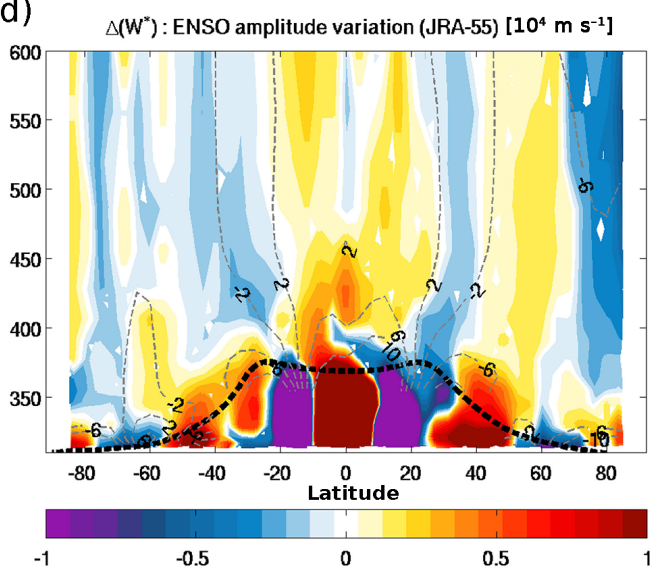

(f)

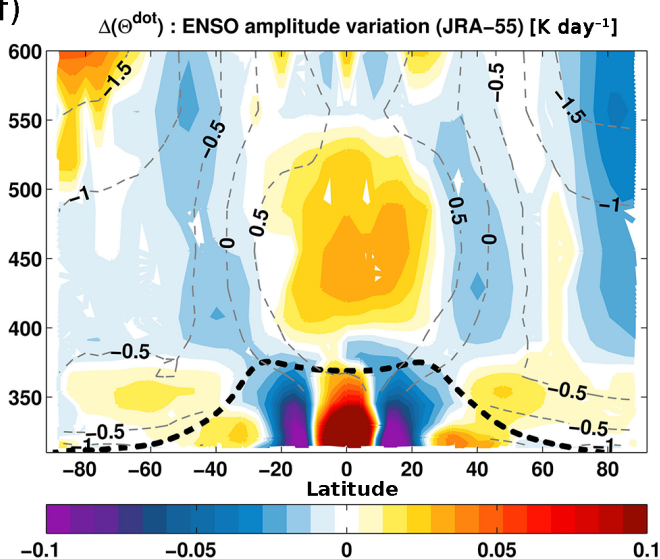

Figure 4. Zonal mean distribution of the ENSO impact on mean age $(\mathbf{a}, \mathbf{b})$, residual vertical velocity $\left(\overline{w^{*}}\right)(\mathbf{c}, \mathbf{d})$ and diabatic heating rate $(\dot{\Theta})(\mathbf{e}, \mathbf{f})$ from CLaMS simulations driven by ERA-I and JRA-55. The mean age anomalies are in percent change relative to the zonal monthly mean climatology. The units of $\overline{w^{*}}$ and $\dot{\Theta}$ are in $\mathrm{m} \mathrm{s}^{-1}$ and $\mathrm{K} \mathrm{day}^{-1}$. The amplitude of the $\mathrm{O}_{3}$ variations (term $b_{2} \times \operatorname{SD}(\mathrm{MEI})$ ) attributed to ENSO is calculated by projecting the regression fits onto the ENSO basis functions for the 1979-2013 period. Black dashed horizontal line indicates the climatological tropopause from ERA-I and JRA-55 reanalyses. Zonal mean climatologies of the mean age, $\overline{w^{*}}$ and $\dot{\Theta}$ are overplotted as dashed grey lines.

tween AoA changes and upwelling or downwelling. Therefore, we also analyse the ENSO-induced RCTT and $\psi^{*}$ anomalies (Fig. 5a-d). The ENSO impact on the vertical structure of the BDC becomes evident from the mass stream function and the RCTT, i.e. the timescale of transport by the pure residual circulation (Fig. 5). In the tropics, El Niño 
(a)

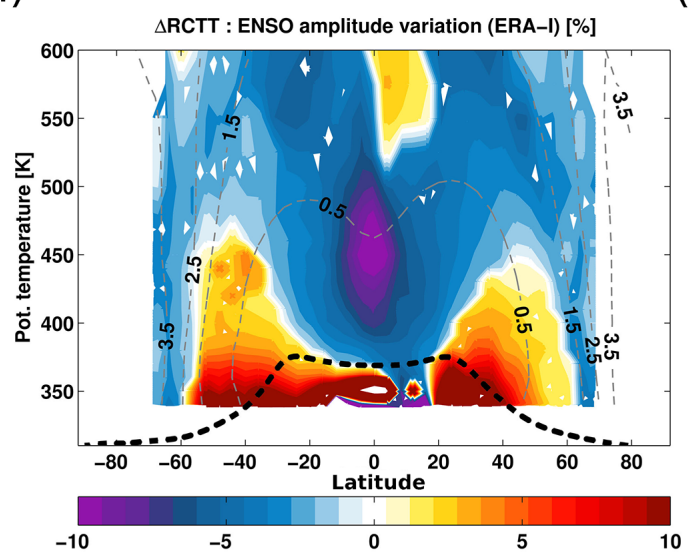

(c)

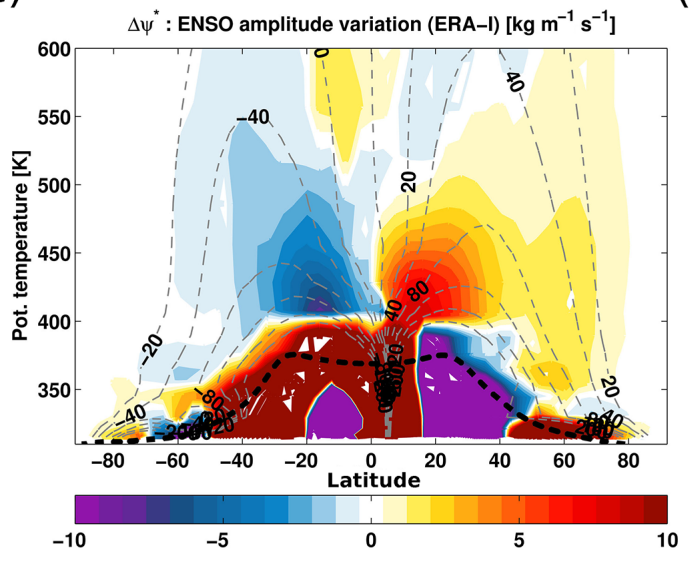

(b)

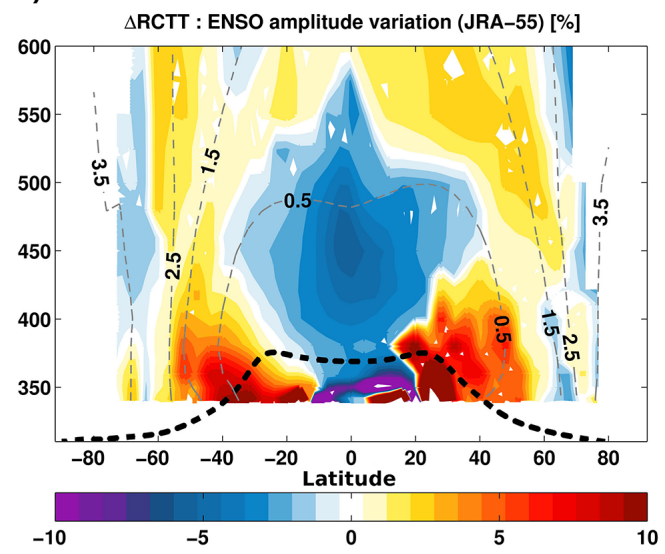

(d)

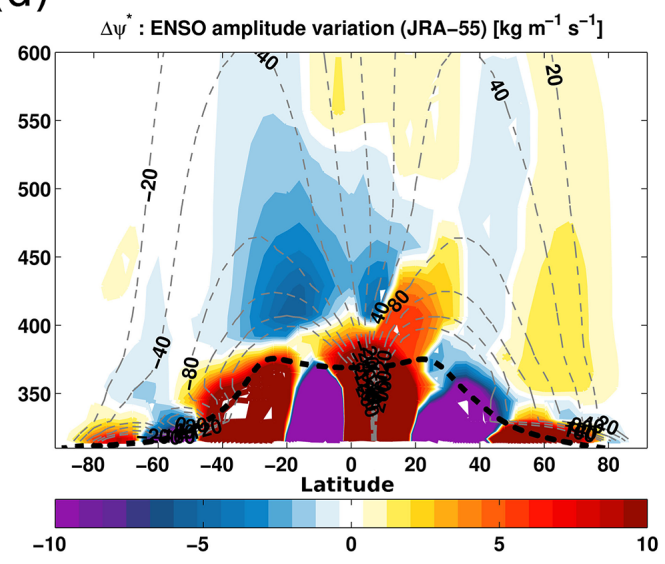

Figure 5. Zonal mean distribution of the ENSO impact on residual circulation transit time (RCTT) (a, b) and the residual circulation mass stream function $\left(\psi^{*}\right)(\mathbf{c}, \mathbf{d})$ from CLaMS simulations driven by ERA-I (a, c) and JRA-55 (b, d). RCTT is shown in percent change relative to the monthly zonal mean climatology. The amplitude of the RCTT and $\psi^{*}$ variations (term $b_{2} \times \operatorname{SD}(\mathrm{MEI})$ ) attributed to the ENSO events is calculated by projecting the regression fits onto the ENSO basis functions for the 1979-2013 period. Black dashed horizontal line indicates the climatological tropopause from ERA-I and JRA-55 reanalyses. Zonal mean climatologies of the RCTT and $\psi^{*}$ are overplotted as dashed grey lines.

causes decreasing RCTT throughout most parts of the stratosphere (below $550 \mathrm{~K}$ ) related to the strengthening tropical residual circulation cell associated with the shallow branch of the BDC (Birner and Bönisch, 2011). The strengthening tropical residual circulation in Fig. $5 \mathrm{a}$, b is consistent with positive (negative) stream function changes in the Northern Hemisphere (Southern Hemisphere), indicating a strengthening residual mean mass circulation in the tropics (Fig. 5c, d). In the extratropical lower stratosphere at altitudes below $450 \mathrm{~K}$, the RCTT increases during El Niño, consistent with a weakening extratropical residual circulation cell related to the transition branch of the BDC (Lin and Fu, 2013). These changes in extratropical RCTT also corroborate a weakening of residual circulation cells in the extratropics of both hemispheres during El Niño. The pattern of changes in the residual circulation (transit time and stream function) depicts a weakening transition branch during El Niño, while the shallow branch is strengthening in both reanalyses. How- ever, differences occur between the two reanalyses concerning the strength of the shallow branch. The strengthening of the shallow branch in response to El Niño does not extend as far poleward in JRA-55 as it does in ERA-I, reflecting the difference in the strength of the tropical upwelling response in the two reanalyses (Fig. 4c, d). ENSO-induced variability in the deep branch is less evident in the reanalyses (not shown).

Next we quantify the changes in the strength of the transition and shallow branches. Figure $6 \mathrm{a}-\mathrm{d}$ show the lag correlation of the ENSO-induced changes in the transition and shallow circulation branches inferred from the RCTT anomalies versus the MEI. A lag correlation is calculated for each given latitude and altitude grid point in these two regions: $20-60^{\circ}$ and $370-420 \mathrm{~K}$ for the transition branch and 10 $60^{\circ}$ and $420-500 \mathrm{~K}$ for the shallow branch. Note that positive lag correlations imply weaker circulation, and negative ones imply stronger circulation. The estimated changes in 
(a)

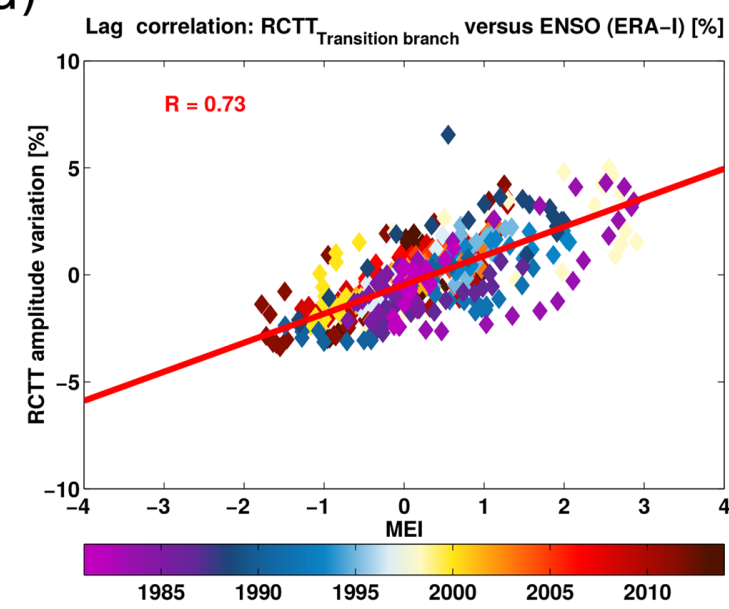

(b)

(c)
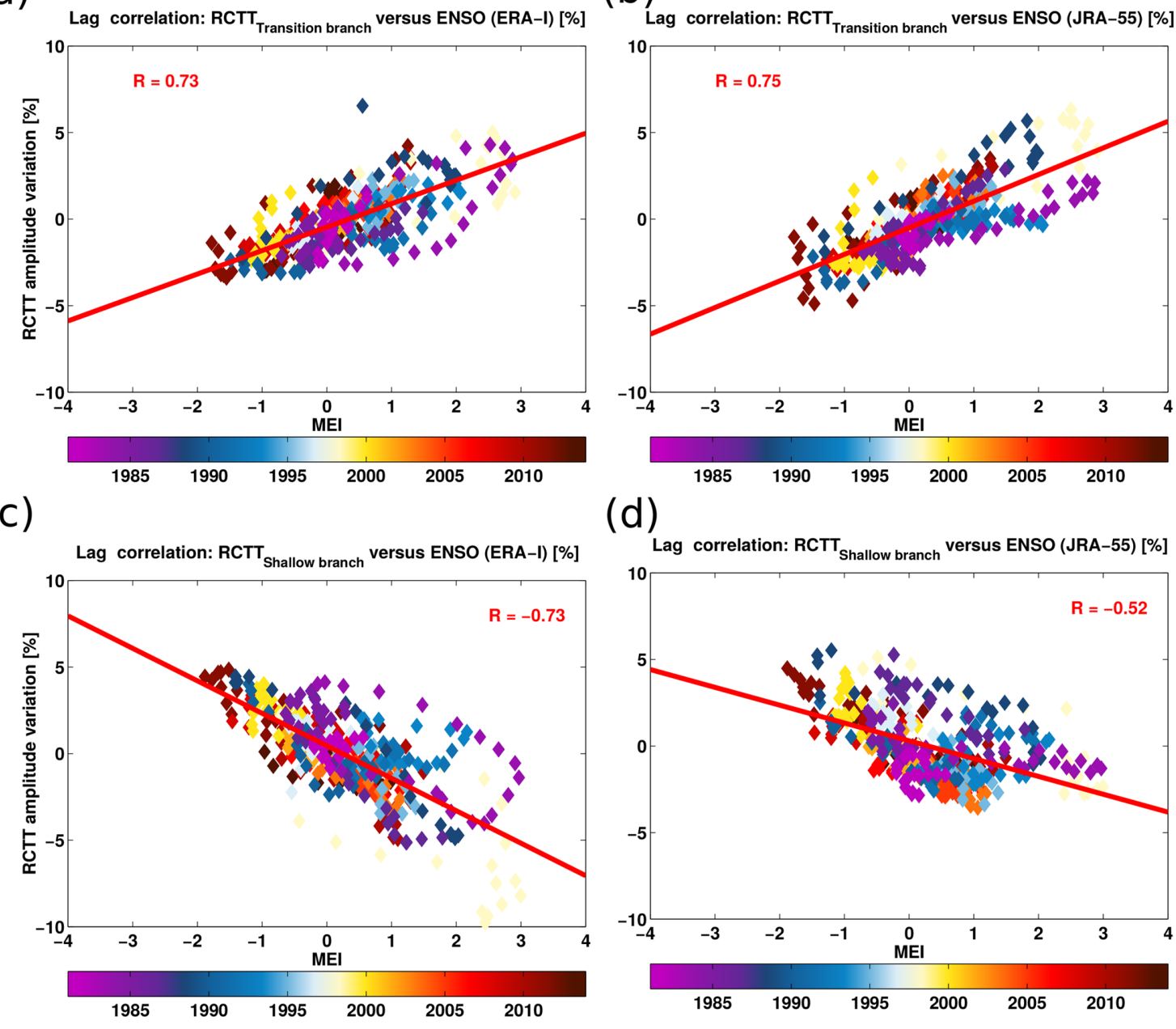

(d)

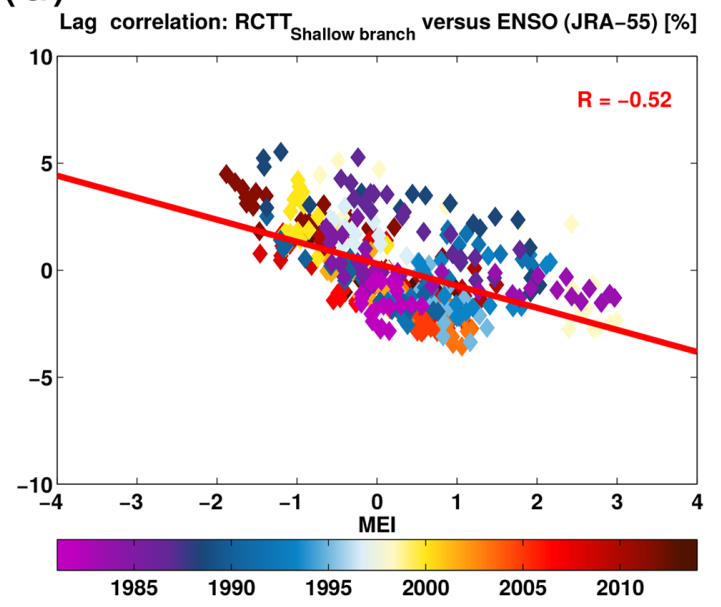

Figure 6. Lag correlation of the ENSO impact on RCTT versus the MEI from CLaMS simulations driven by ERA-I (a, c) and JRA-55 (b, d). Transition branch $(\mathbf{a}, \mathbf{b})$ and shallow branch $(\mathbf{c}, \mathbf{d})$ changes are shown in percent change relative to the monthly zonal mean climatology. The RCTT variations attributed to the ENSO events using the regression analysis are averaged between 20 and $70^{\circ}$ and between 370 and $420 \mathrm{~K}$ for the transition branch and between 10 and $70^{\circ}$ and between 420 and $500 \mathrm{~K}$ for the shallow branch during the $1979-2013$ period.

the transition and shallow branches are as large as $\pm 8 \%$ over the 1979-2013 period, except the strong Niño in 1997, where the changes in the shallow branch from ERA-I reach $-10 \%$. These changes are robust as, shown by the lag correlation estimated from the transition branch versus MEI, which reaches $73 \%$ for ERA-I and $75 \%$ for JRA-55. For the shallow branch, the lag correlation is $-73 \%$ for ERAI and $-53 \%$ for JRA-55. The vertical structure of changes in the BDC during El Niño with a strengthening ascending branch and a weakening circulation in the mid-latitude lower stratosphere is also consistent with the strengthening shallow circulation branch and a weakening transition branch. The vertical structure of the BDC branches agrees between the two reanalyses, although the changes in JRA-55 are more confined in latitude and altitude than changes in ERA-I, consistent with the variations in diabatic heating rates related to
ENSO in the two reanalyses (Fig. 4e, f) as well as with the differences in the lag correlation.

The most complete transit time diagnostic is the age spectrum, which includes the full transit time information related to all circulation pathways and mixing processes, thereby giving clearer insight into the reanalysis differences. From Fig. 7a to d, it can be concluded that the ENSO-induced variations in the age spectrum appear to be mainly caused by changes in the residual circulation and mass stream function (Fig. 5). The El Niño and La Niña impacts on the fraction of young air masses in the tropics and extratropics are consistent with the structural changes in the residual circulation induced by ENSO. Both reanalyses show an increase in the fraction of young air masses with age shorter than about 6 months during El Niño and a significant decrease during La Niña in the tropical lower stratosphere (here $10^{\circ} \mathrm{S}-10^{\circ} \mathrm{N}$ at $400 \mathrm{~K}$ ) (Fig. 7a, b). Note that JRA-55 depicts a smaller El 

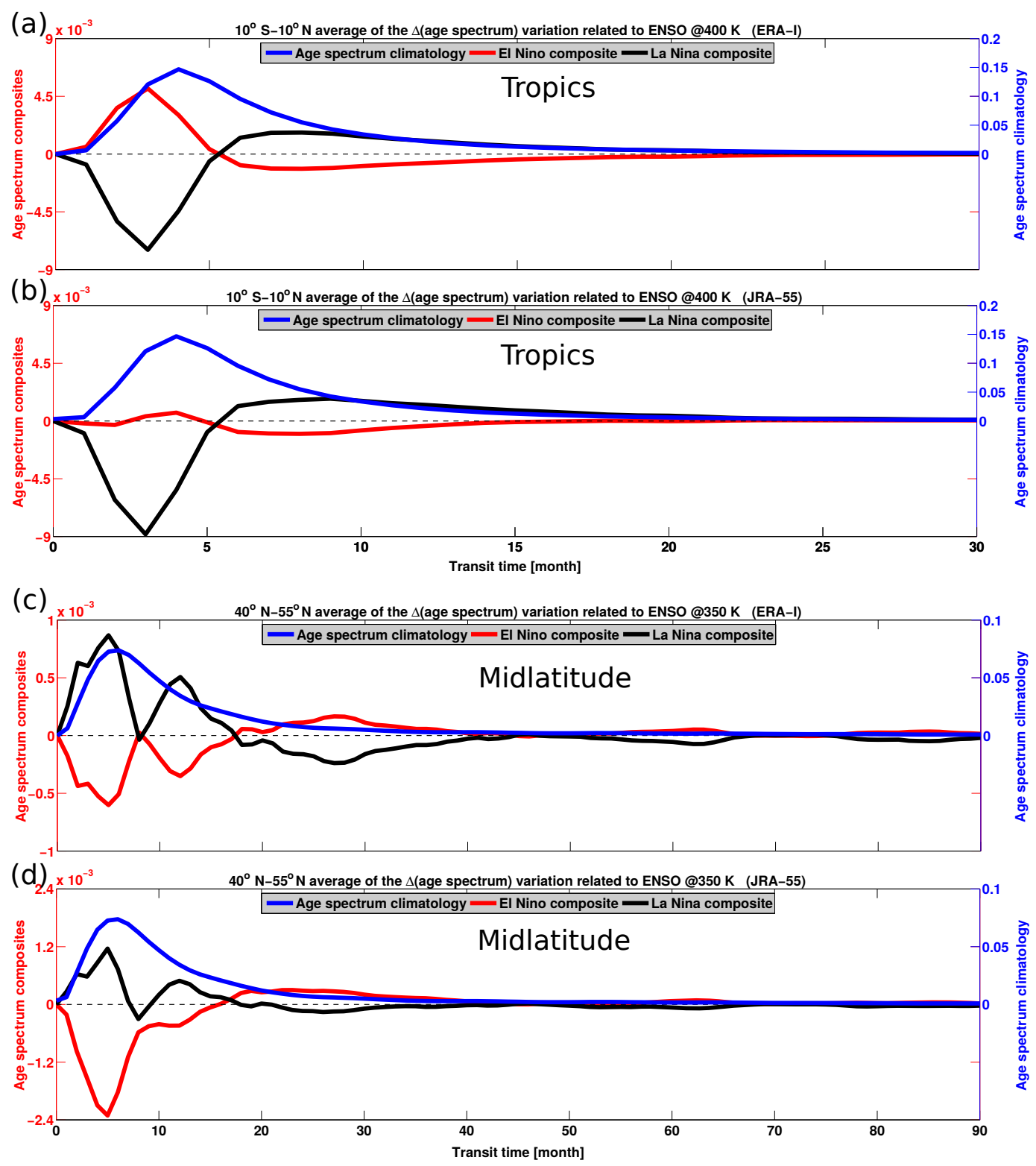

Figure 7. ENSO impact on the monthly mean age spectrum from CLaMS simulations driven by ERA-I and JRA-55 reanalyses for the 1979-2013 period: (a, b) tropics at $400 \mathrm{~K}$ and $(\mathbf{c}, \mathbf{d})$ mid latitudes at $350 \mathrm{~K}$. The El Niño and La Niña composites shown are derived from the multiple regression fit as the difference between the residual ( $\epsilon$ in Eg. 1) without and with explicit inclusion of the ENSO signal. Note that the $x$ axes for the tropic and mid-latitude panels are not the same. The ERA-I and JRA-55 mid-latitude panels use different $y$-axis ranges. The $x$-axis ranges of the tropical panels stop at 30 months, while the $x$-axis ranges of the mid-latitude panels stop at 90 months.

Niño impact on the youngest air mass fraction than ERAI, consistent with the reanalysis differences in the RCTTs (Fig. 5). The age spectrum tail, which is most sensitive to changes in mixing with very old air from the extratropics, is unchanged in both reanalyses after 25 months. Hence, the ENSO-induced changes in the tropical age spectrum mainly reflect the strengthening upwelling branch of the residual circulation in the tropics during El Niño, in agreement with the discussion by Konopka et al. (2016). In the lower stratosphere at mid latitudes (here $40-55^{\circ} \mathrm{N}$ at $350 \mathrm{~K}$ ), the age spectrum shows a decrease in the fraction of young air and a slight change in the spectrum tail after 40 months during El Niño, indicating a long-lasting ENSO signal in the Northern Hemisphere and mixing effects (Fig. 7c, d). The amplitude of decreasing young air mass fraction during El Niño is larger in JRA-55 than in ERA-I, corroborating the observed differences in the AoA and RCTTs (Figs. 4 and 5). These changes in the age spectrum are consistent with the weakening transition branch of the residual circulation in the lowermost stratosphere at mid latitudes (see Fig. 5 and re- 
lated discussion). Hence, the ENSO-induced changes in the lower stratospheric age spectra are consistent with the structural changes in the residual circulation, with El Niño causing an upward shift of the poleward outflow from the shallow branch of the BDC and a weakening of the transition branch below. La Niña causes the opposite changes.

A very clear picture of the structural circulation changes induced by ENSO emerges from the separation of the young air mass fraction with a transit time shorter than 6 months (Fig. 8a, b) and the old air mass fraction with a transit time longer than 24 months (Fig. 8c, d), calculated from the age spectrum. During El Niño, the young air mass fraction with a transit time shorter than 6 months increases throughout the tropical lower stratosphere and extends poleward in the layer between about 400 and $500 \mathrm{~K}$. These changes in young air mass fraction are consistent with a strengthened shallow branch. In contrast, below about $400 \mathrm{~K}$, the poleward transport of young tropical air weakens, and a negative young air anomaly even occurs during El Niño, consistent with the weakening transition branch and isolated mid-latitudinal regions. Hence, El Niño clearly strengthens the shallow branch of the BDC $(420-500 \mathrm{~K})$ and weakens the transition branch in both reanalyses, with a hemispheric asymmetry. The ENSO-induced variations in the air mass fraction with a transit time longer than 24 months consistently show a significant decrease in the tropics and a significant increase in the extratropics in both reanalyses during El Niño (Fig. 8c, d). Differences between ERA-I and JRA-55 reanalyses are larger in the old air mass fractions, especially in the extratropics above $400 \mathrm{~K}$, where JRA-55 exhibits larger positive anomalies in older air mass fractions than ERA-I. The signal of the old air mass fraction with a transit time longer than 24 months from JRA-55 spreads throughout the lower stratosphere except in the tropics. Despite the differences in the distribution of the old air mass fraction between ERA-I and JRA-55 reanalyses, the decrease in old air in the tropics and the increase in old air in the extratropics is consistent between the two reanalyses. Note that the ENSO-induced changes are less evident above about $600 \mathrm{~K}$ (not shown), indicating that the ENSO impact on the BDC is largely confined to the region below and hence to the transition and shallow branches.

\section{Discussion}

In a recent study, Yang et al. (2014) showed from an idealized model that zonally symmetric SST perturbations drive the deep branch of the stratospheric BDC, whereas zonally localized SST perturbations drive the shallow circulation branch. Here, we find no clear evidence of an El Niño effect on the deep branch of the BDC above about $600 \mathrm{~K}$. Nevertheless, our results are consistent with the findings of Yang et al. (2014), who suggested that a zonally symmetric anomalous SST pattern like during El Niño strengthens the shal- low branch of the BDC and suppresses the isentropic mixing induced by a stronger subtropical jet. Furthermore, we found evidence that El Niño alters the two sub-branches of the BDC, i.e. strengthens the shallow branch between about 420 and $500 \mathrm{~K}$ and weakens the transition branch between about 370 and $420 \mathrm{~K}$. The strengthening of the deep branch related to El Niño is less evident in the reanalyses examined here.

Insight into the underlying dynamical mechanism causing the changes in the transition and shallow branches of the BDC is derived from the temperature, zonal mean wind, Eliassen-Palm flux (EP flux), and EP-flux divergence variations related to ENSO (Fig. 9). Generally both reanalyses agree well in ENSO-induced variations in temperature, zonal mean wind, and EP-flux divergence anomalies. In the tropics $\left(30^{\circ} \mathrm{S}-30^{\circ} \mathrm{N}\right)$, El Niño clearly warms the upper troposphere and cools the lower stratosphere in both reanalyses, consistent with previous studies (e.g. Randel et al., 2009; Calvo et al., 2010; Simpson et al., 2011). Large tropical temperature changes remain confined below about $500 \mathrm{~K}$. In the extratropics, El Niño generally warms the whole lower stratosphere, except below about $400 \mathrm{~K}$ near the subtropical jets, where negative temperature anomalies occur (Fig. 9a, d). The cooling of the tropical stratosphere and warming of the extratropical lower stratosphere are consistent with the increased tropical upwelling and extratropical downwelling during El Niño. In addition, the negative temperature anomalies in the mid latitudes are consistent with a weakening transition branch. The strong differences in the temperature changes between the upper tropical troposphere and the mid latitudes (i.e. a strong tropical-mid-latitudinal temperature gradient) cause a strengthening of the subtropical and polar zonal jets on their equatorward flanks, resulting in an equatorward and upward shift of the subtropical jet $\left(\sim 10^{\circ}\right.$ and $\sim 10 \mathrm{~K}$ ) (Fig. 9b, e), consistent with the results of Lorenz and DeWeaver (2007). According to Simpson et al. (2011), this equatorward shift of the mid-latitude jet related to El Niño results in an enhanced source of waves with higher phase speeds in the mid latitudes and changed propagation characteristics into the stratosphere. Recently, Albers et al. (2018) also attributed the ENSO-related jet variability to wave breaking frequency rather than to the typical ENSO teleconnection patterns. The temperature and zonal mean wind variations induced by El Niño shown in Fig. 9 agree with prior model and observational studies (e.g. Lu et al., 2008; Simpson et al., 2011; Abalos et al., 2017; Zhou et al., 2018) and with the idealized model results from Yang et al. (2014). This ENSO-induced variability in temperatures and zonal wind can be understood as a direct response to the zonal extent of the SST perturbations.

The changes in EP-flux divergence related to El Niño show positive anomalies at lower levels close to the tropopause and negative anomalies in the mid-latitude lower stratosphere above about $420 \mathrm{~K}$ (Fig. 9c, f). The positive anomalies suggest decreased wave breaking at lower levels in the lower 
(a)

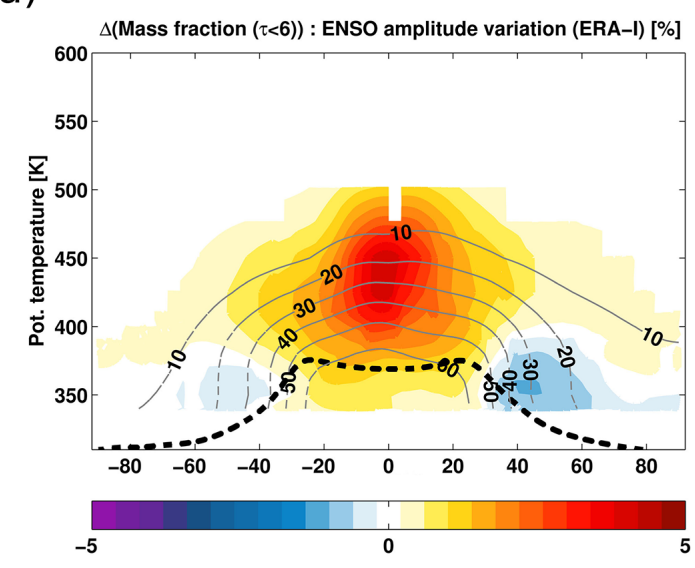

(c)

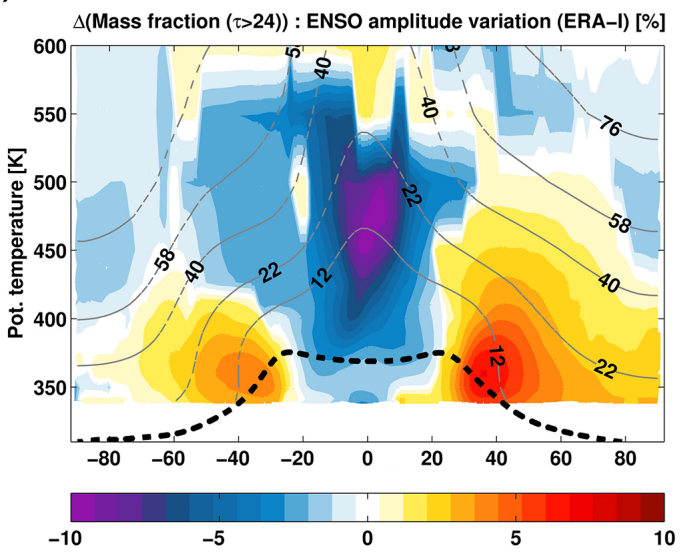

(b)

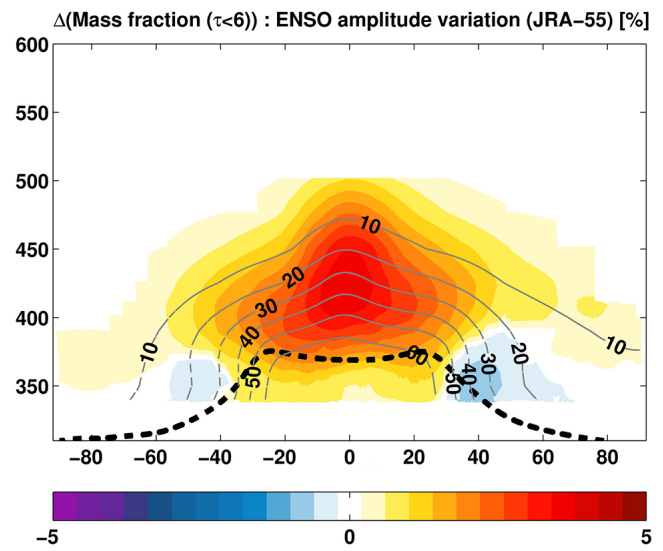

(d)

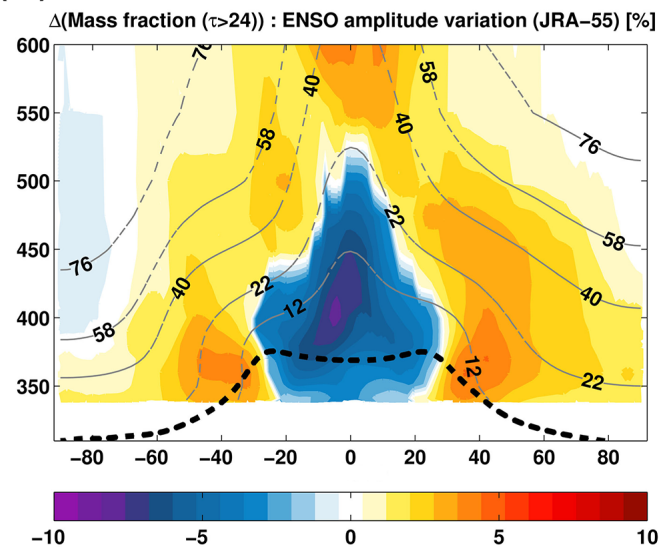

Figure 8. Zonal mean distribution of the ENSO impact on monthly mean young and old air mass fraction from CLaMS simulations driven by (a, c) ERA-I and (b, d) JRA-55 reanalyses. The amplitude of the air mass fraction variations (term $b_{2} \times \mathrm{SD}(\mathrm{MEI})$ ) attributed to ENSO is calculated by projecting the regression fits onto the ENSO basis functions for the 1979-2013 period. ENSO amplitude variation of the young air mass fraction with a transit time $\tau$ shorter than 6 months is shown in (a) and (b) panels. ENSO amplitude variation of the old air mass fraction with a transit time $\tau$ longer than 24 months is shown in (c) and (d) panels. Grey contours are the climatology. Black dashed horizontal line indicates the climatological tropopause from ERA-I and JRA-55 reanalyses.

stratosphere during El Niño (McLandress and Shepherd, 2009; Calvo et al., 2010; Simpson et al., 2011), consistent with the weakening of the transition branch. In contrast, the negative anomalies above indicate that more waves break at higher levels in the extratropical lower stratosphere, depositing their momentum flux in these regions and therefore accelerating the shallow branch (Fig. 9c, f). Hence, the wave drag changes shown in Fig. 9c, f are qualitatively consistent with a weakening of the transition branch of the BDC and a strengthening of the shallow branch during El Niño. These wave drag changes are also consistent with the findings of Zhou et al. (2018), who concluded that the magnitudes of the stratospheric zonal mean responses are larger in the case of extreme El Niño events, as the strong upward propagation of planetary-scale waves induces a weaker Northern Hemisphere polar vortex by breaking at high latitudes.

Gravity waves have been shown to play an important role in driving ENSO-related variations in the lower stratospheric circulation, particularly in the subtropics (Calvo et al., 2010; Simpson et al., 2011). According to Alexander et al. (2017), zonal gravity wave momentum fluxes at the tropopause were $11 \%$ smaller during El Niño than during La Niña because of a shift in the precipitation to the central Pacific, where upper tropospheric zonal winds are less favourable for vertical wave propagation. According to Kawatani et al. (2010), zonal mean variation of wave forcings in the stratosphere results from the phase of the QBO and the changes in wave sources, i.e. the vertical shear of zonal mean winds associated with the Walker circulation. Hence, close agreement between the ENSO variations in the wave drag and the residual circulation variations is not necessarily expected, due to the strong effect of gravity waves.

To quantify the contribution of wave drag to the changes in the transition and shallow branches of the BDC induced by El Niño, the zonal mean wave drag of the explicitly resolved waves (both global-scale and gravity waves) is calcu- 
(a)

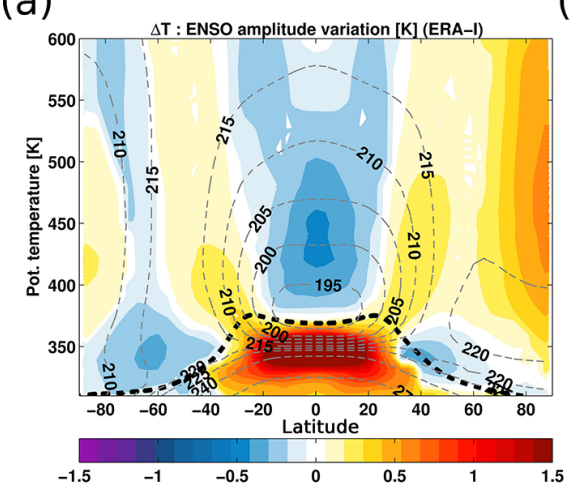

(d)

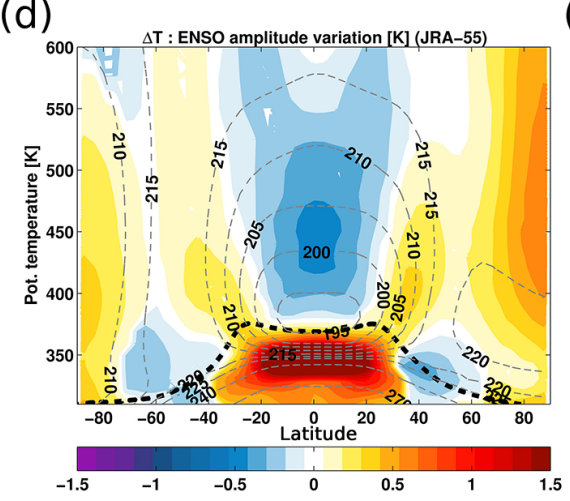

(b)

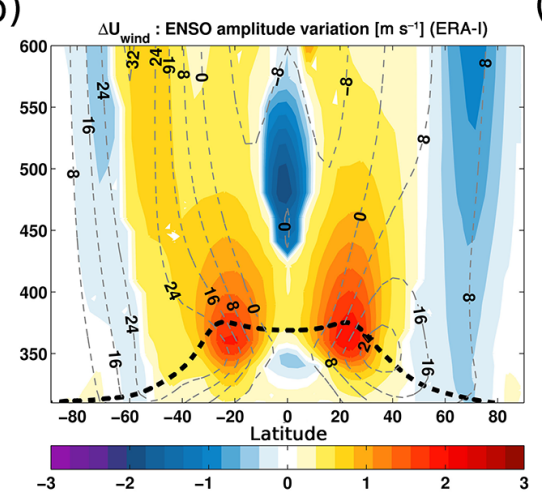

(e)

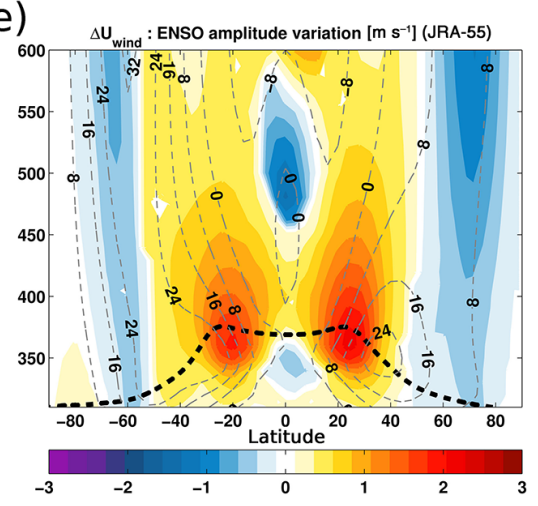

(c)

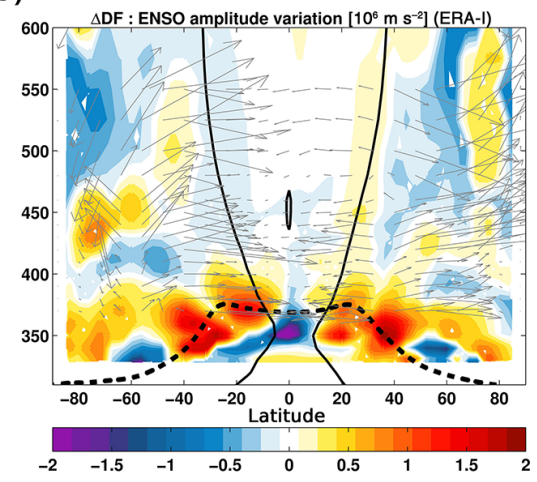

(f)

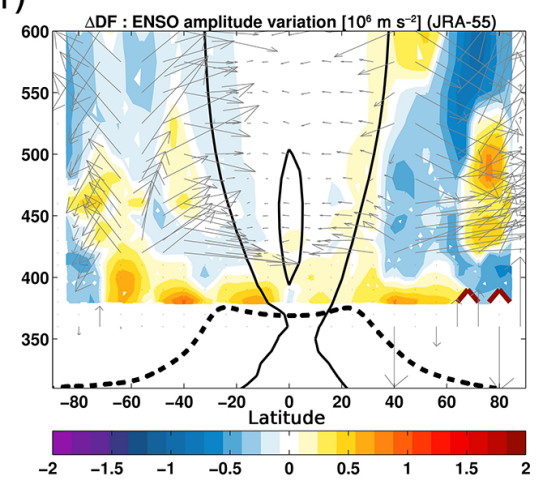

Figure 9. Zonal mean distribution of the ENSO impact on monthly mean temperature (K), zonal wind ( $\mathrm{m} \mathrm{s}^{-1}$ ), and EP flux and its divergence $\left(\mathrm{m} \mathrm{s}^{-2}\right)$ derived from (a-c) ERA-I and (d-f) JRA-55 reanalyses. The amplitude of the temperature, zonal wind, and EP-flux variations (term $\left.b_{2} \times \mathrm{SD}(\mathrm{MEI})\right)$ attributed to the ENSO events is calculated by projecting the regression fits onto the ENSO basis functions for the 1979-2013 period. Black dashed horizontal line indicates the climatological tropopause from ERA-I and JRA-55 reanalyses. Zonal mean climatologies are overplotted as dashed grey lines. The thick black line in Fig. 8c, f indicates the zero line zonal mean wind. The arrows indicate the EP-flux vectors.

lated from the divergence of the EP flux using ERA-I. The estimate for the planetary wave drag is then obtained by integrating the EP-flux divergence over zonal wave numbers 120. According to Alexander and Rosenlof (1996), the missing wave drag in ERA-I can be assumed to be the part of the contribution of gravity wave drag in the zonal mean momentum budget that is not explicitly resolved by the model grid, and its relative variations should still contain valuable information. The total gravity wave drag is estimated as the sum of the missing drag and the model-resolved waves integrated over zonal wave numbers $21-180$. Fore more details about the calculations and inter-comparisons of the ERA-I wave drag with those derived from satellite observations, see Ern et al. (2014, 2015, 2016).

Figure 10a-c show the zonal mean distribution of the ENSO impact on monthly mean net wave forcings (PWD $+\mathrm{GWD}-\mathrm{d} u / \mathrm{d} t$ ) (a), planetary wave drag (PWD) (b), and gravity wave drag (GWD) (c). The net wave forcings (Fig. 10a) explain the changes in the branches and the hemispheric asymmetry to a remarkable degree. Clearly, the weakening of the transition branch is due to an upward shift in the wave dissipation height up to $425 \mathrm{~K}$, while the strengthening of the shallow branch results from wave breaking above $425 \mathrm{~K}$. The hemispheric asymmetry is a consequence of the asymmetry in both wave distributions (globalscale and gravity), with a larger contribution in the Northern Hemisphere than the Southern Hemisphere. Most of the ENSO-induced variations in wave forcing are contained in the zonal wavenumbers up to 20 (global-scale waves) and are focused around the tropopause. In the Northern Hemisphere, there is a positive pattern of planetary wave changes above the tropopause and a negative pattern below the tropopause over a wide latitude range in the extratropics (Fig. 10b), consistent with results from the WACCM model (see Fig. 3 of Calvo et al., 2010). This pattern of changes indicates an altitude shift in the dissipation height of the global-scale waves. In the Southern Hemisphere, the pattern of planetary wave changes is somewhat different and indicates a general shift towards positive values. For the gravity wave response to $\mathrm{El}$ Niño, Fig. 10c shows a positive response in the subtropics around $380 \mathrm{~K}$, i.e. a reduction in wave drag, which is however weaker than the planetary wave response. Interestingly, there is a negative response at higher altitudes in the Northern Hemisphere subtropics between 425 and $550 \mathrm{~K}$, i.e. an 
(a)

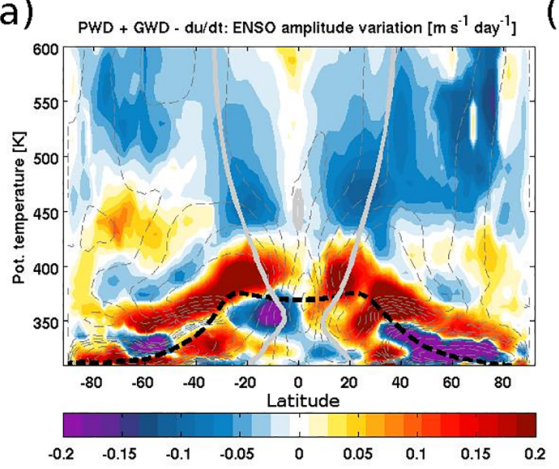

(b)

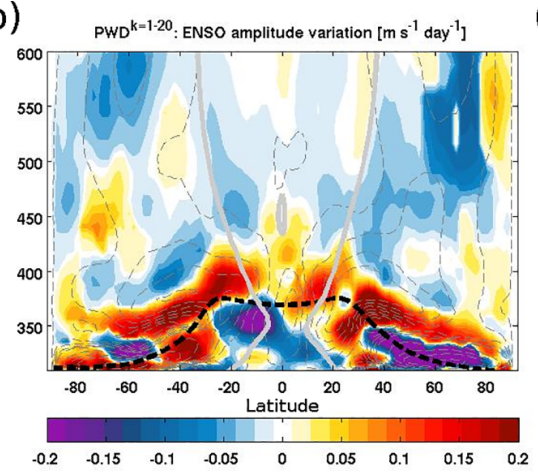

(c)

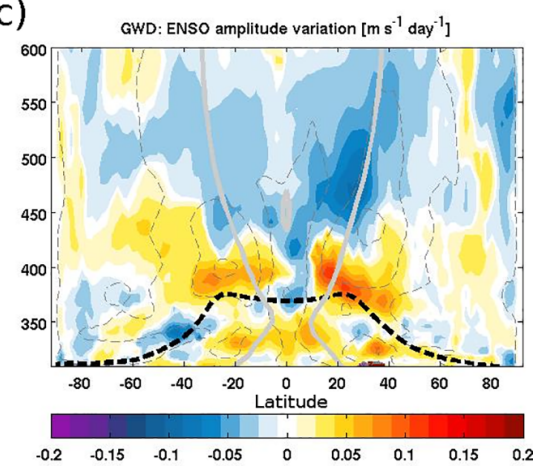

Figure 10. Zonal mean distribution of the ENSO impact on monthly mean net resolved wave drag (a), planetary wave drag (PW) (d), and gravity wave drag (c) derived from ERA-I reanalysis. The amplitude variations (term $b_{2} \times \mathrm{SD}(\mathrm{MEI})$ ) attributed to the ENSO events is calculated by projecting the regression fits onto the ENSO basis functions for the 1979-2013 period. Black dashed horizontal line indicates the climatological tropopause from ERA-I. Zonal mean climatologies are overplotted as dashed grey lines. The thick grey line indicates the zero line zonal mean wind.

increase in wave drag, that is even stronger than the response for the zonal wavenumbers up to 20 (Fig. 10b). In summary, the altitude shift in the dissipation height of the large-scale and gravity waves clearly causes the slowdown of the transition branch, while the gravity wave breaking in the tropicssubtropics combined with planetary wave breaking at high latitudes drive the acceleration of the shallow branch. Gravity wave breaking in the subtropics close to the edge of the upwelling region contributes the most to the strengthening of the tropical upwelling. Driven by the wave breaking, the mixing efficiency between tropics and extratropics will be different in the Northern Hemisphere and Southern Hemisphere, leading to the observed hemispheric asymmetry. In addition to the lack of tropospheric $\mathrm{O}_{3}$ chemistry and the $\mathrm{O}_{3}$ lower boundary condition set to zero in CLaMS, uncertainties in the upwelling strength also contribute to the factor of 2 difference observed in the $\mathrm{O}_{3}$ anomalies (Figs. 1-3).

Future projections of climate models predict a shift of the ENSO basic state toward more frequent El Niño conditions in a warming climate due to an increase in anthropogenic greenhouse gases (Timmermann et al., 1999; van Oldenborgh et al., 2005; Latif and Keenlyside, 2009; Cai et al., 2014). As changes in UTLS trace gases, including $\mathrm{O}_{3}$ and $\mathrm{H}_{2} \mathrm{O}$ (Solomon et al., 2010; Riese et al., 2012), directly impact the global radiative forcing of climate (Forster and Shine, 1999; Butchart and Scaife, 2001), it is crucial to understand such future changes in trace gases induced by a shift of the ENSO basic state toward more frequent El Niñolike conditions. Despite the uncertainty in the magnitude of the future El Niño events, we speculate that the projected change in the El Niño occurrence frequency will cause structural changes similar to the current $\mathrm{O}_{3}$, RCTT and $\dot{\theta}$ anomalies (Figs. 3, 4 and 5). In a future climate characterized by a shift of the basic state toward more frequent El Niño conditions, the negative $\mathrm{O}_{3}$ anomalies in the tropics and positive $\mathrm{O}_{3}$ anomalies in the mid latitudes will strengthen (by at least $15 \%$ ), enhancing stratosphere-to-troposphere of ozone mass flux (Holton et al., 1995; Hegglin and Shepherd, 2009; Zeng et al., 2010; Neu et al., 2014; Yang et al., 2016; Albers et al., 2018; Meul et al., 2018) and stronger ozone radiative feedback (Forster and Shine, 1997; Birner and Charlesworth, 2017; Ming et al., 2017).

\section{Summary and conclusions}

Based on an established multiple regression method applied to MLS observations and CLaMS simulations driven by ERA-I and JRA-55 reanalyses, we found that ENSO induces structural changes in the BDC in the lower stratosphere. These structural changes in the BDC lead to substantial changes in the tropical and mid-latitudinal lower stratospheric $\mathrm{O}_{3}$ anomalies of about $15 \%$ for MLS observations with a hemispheric asymmetry (i.e. stronger $\mathrm{O}_{3}$ changes in the Northern Hemisphere than in the Southern Hemisphere). This circulation asymmetry results from the asymmetry in the wave breaking response to ENSO.

The regression analysis of different metrics of the circulation strength related to ENSO, including mean AoA, $\overline{w^{*}}$, RCTT, $\psi^{*}$, and age spectra, shows structural changes in the lower stratospheric BDC branches, consistent with observed $\mathrm{O}_{3}$ anomalies. The ENSO influence on the BDC turns out to be mainly evident for the transition and shallow circulation branches (Birner and Bönisch, 2011; Lin and Fu, 2013). During El Niño, the transition branch (370-420 K) weakens, while the shallow branch $(420-500 \mathrm{~K})$ strengthens. These structural changes in the transition and shallow branches are as large as $\pm 8 \%$ and are tightly linked to the dynamical response of the atmosphere to ENSO. During El Niño, the strengthened tropical-mid-latitudinal temperature gradient induces a strengthening of the subtropical zonal jets on their equatorward flanks, resulting in an equatorward and up- 
ward shift of the subtropical jet. This equatorward shift of the mid-latitude jet induced by El Niño results in enhanced wave propagation towards the extratropical lower stratosphere and breaking therein, consistent with the structural changes in the BDC. The decomposition of the wave drag into planetary and gravity wave drags led to a quantification of the contributions of these two groups to the weakening transition and strengthening shallow branches. The upward shift in the dissipation height of the large-scale and gravity waves drives the slowdown of the transition branch, while enhanced gravity wave breaking in the tropics-subtropics (above about $425 \mathrm{~K}$ ) mainly drives the acceleration of the shallow branch combined with a contribution from planetary wave breaking at high latitudes. The contribution of gravity waves mainly predominates in the strengthening of the shallow branch. During La Niña, opposite change occurs (not shown).

These structural circulation changes related to ENSO affect the distributions of radiatively active trace gases in the UTLS, including $\mathrm{O}_{3}$, which, in turn, crucially impact the global radiation budget (Forster and Shine, 1999; Butchart and Scaife, 2001). Hence, the ENSO influence on the structure of the BDC in the UTLS opens a pathway for a stratospheric impact on future climate. It is thus necessary, that climate models represent these processes well to achieve reliable climate projections. Our results suggest that in the context of a changing future climate, where increasing El Niño-like conditions (Timmermann et al., 1999; Cai et al., 2014) and decreasing lower stratospheric QBO amplitude (Kawatani and Hamilton, 2013) are expected, the ENSO effect will be increasingly important for controlling the distributions of radiatively active greenhouse gases in the UTLS.

Data availability. The Aura Microwave Limb Sounder product (http://disc.sci.gsfc.nasa.gov/Aura/data-holdings/MLS/index. shtml, last access: 20 November 2018, Livesey et al., 2017; Santee et al., 2017) and ERA-Interim reanalysis data (https://www.ecmwf. int/en/forecasts/datasets/reanalysis-datasets/era-interim, last access: 20 November 2018, Dee et al., 2011) are available. The $\mathrm{O}_{3}$, AoA, $\overline{w^{*}}$, RCTT and age spectrum data set can be requested from the corresponding author Felix Ploeger (f.ploeger@ fz-juelich.de).

Author contributions. All co-authors made substantial contributions to the analysis, interpretation of the data as well as contributing to provide the analysed data and drafting the article.

Competing interests. The authors declare that they have no conflict of interest.

Special issue statement. This article is part of the special issue "The SPARC Reanalysis Intercomparison Project (S-RIP) (ACP/ESSD inter-journal SI)". It is not associated with a conference.
Acknowledgements. We particularly thank the NASA Jet Propulsion Laboratory, the European Centre for Medium-Range Weather Forecasts and the Japan Meteorological Agency for providing Aura Microwave Limb Sounder product (https://mls.jpl.nasa.gov/, last access: 9 January 2019), the ERA-Interim and JRA-55 reanalyses data. Work at the Jet Propulsion Laboratory, California Institute of Technology, was done under contract with the National Aeronautics and Space Administration. This work was funded by the Helmholtz Association under grant number VH-NG-1128 (Helmholtz-Hochschul-Nachwuchsforschergruppe), enabling a research stay at the Institute of Energy and Climate Research, Stratosphere (IEK-7), Forschungszentrum in Jülich during which this work was carried out.

The article processing charges for this open-access publication were covered by a Research Centre of the Helmholtz Association.

Edited by: Gabriele Stiller

Reviewed by: two anonymous referees

\section{References}

Abalos, M., Legras, B., Ploeger, F., and Randel, W. J.: Evaluating the advective Brewer-Dobson circulation in three reanalyses for the period 1979-2012, J. Geophys. Res.-Atmos., 120, 7534 7554, https://doi.org/10.1002/2015JD023182, 2015.

Abalos, M., Randel, W. J., Kinnison, D. E., and Garcia, R. R.: Using the Artificial Tracer e90 to Examine Present and Future UTLS Tracer Transport in WACCM, J. Atmos. Sci., 74, 3383-3403, https://doi.org/10.1175/JAS-D-17-0135.1, 2017.

Albers, J. R., Perlwitz, J., Butler, A. H., Birner, T., Kiladis, G. N., Lawrence, Z. D., Manney, G. L., Langford, A. O., and Dias, J.: Mechanisms Governing Interannual Variability of Stratosphere to Troposphere Ozone Transport, J. Geophys. Res.-Atmos., 123, 234-260, https://doi.org/10.1002/2017JD026890, 2018.

Alexander, M. J. and Rosenlof, K. H.: Nonstationary gravity wave forcing of the stratospheric zonal mean wind, J. Geophys. Res.Atmos., 101, 23465-23474, https://doi.org/10.1029/96JD02197, 1996.

Alexander, M. J., Ortland, D. A., Grimsdell, A. W., and Kim, J.-E.: Sensitivity of Gravity Wave Fluxes to Interannual Variations in Tropical Convection and Zonal Wind, J. Atmos. Sci., 74, 27012716, https://doi.org/10.1175/JAS-D-17-0044.1, 2017.

Andrews, D. G., Holton, J. R., and Leovy, C. B.: Middle Atmosphere Dynamics, vol. 40 of International Geophysics Series, Academic Press, San Diego, USA, 1987.

Avery, M. A., Davis, S. M., Rosenlof, K. H., Ye, H., and Dessler, A. E.: Large anomalies in lower stratospheric water vapour and ice during the 2015-2016 El Niño, Nat. Geosci., 10, 405-409, https://doi.org/10.1038/ngeo2961, 2017.

Baldwin, M. P. and O'Sullivan, D.: Stratospheric Effects of ENSORelated Tropospheric Circulation Anomalies, J. Clim., 8, 649667, 1995.

Ball, W. T., Alsing, J., Mortlock, D. J., Staehelin, J., Haigh, J. D., Peter, T., Tummon, F., Stübi, R., Stenke, A., Anderson, J., Bourassa, A., Davis, S. M., Degenstein, D., Frith, S., Froidevaux, L., Roth, C., Sofieva, V., Wang, R., Wild, J., Yu, P., Ziemke, 
J. R., and Rozanov, E. V.: Evidence for a continuous decline in lower stratospheric ozone offsetting ozone layer recovery, Atmos. Chem. Phys., 18, 1379-1394, https://doi.org/10.5194/acp18-1379-2018, 2018.

Banerjee, A., Maycock, A. C., Archibald, A. T., Abraham, N. L., Telford, P., Braesicke, P., and Pyle, J. A.: Drivers of changes in stratospheric and tropospheric ozone between year 2000 and 2100, Atmos. Chem. Phys., 16, 2727-2746, https://doi.org/10.5194/acp-16-2727-2016, 2016.

Bekki, S., Rap, A., Poulain, V., Dhomse, S., Marchand, M., Lefevre, F., Forster, P., Szopa, S., and Chipperfield, M.: Climate impact of stratospheric ozone recovery, Geophys. Res. Lett., 40, 27962800, https://doi.org/10.1002/grl.50358, 2013.

Bence, J. R.: Analysis of short time series: Correcting for autocorrelation, Ecology, 76, 628-639, 1995.

Birner, T. and Bönisch, H. B.: Residual circulation trajectories and transit times into the extratropical lowermost stratosphere, Atmos. Chem. Phys., 11, 817-827, https://doi.org/10.5194/acp-11817-2011, 2011.

Birner, T. and Charlesworth, E. J.: On the relative importance of radiative and dynamical heating for tropical tropopause temperatures, J. Geophys. Res., 122, 6782-6797, https://doi.org/10.1002/2016JD026445, 2017.

Bjerknes, J.: Atmospheric teleconnections from the equatorial Pacific, Mon. Weather Rev., 97, 163-172, 1969.

Bönisch, H. B., Engel, A., Birner, T., Hoor, P., Tarasick, D. W., and Ray, E. A.: On the structural changes in the Brewer-Dobson circulation after 2000, Atmos. Chem. Phys., 11, 3937-3948, https://doi.org/10.5194/acp-11-3937-2011, 2011.

Brewer, A.: Evidence for a world circulation provided by the measurements of helium and water vapour distribution in the stratosphere, Q. J. R. Meteorol. Soc., 75, 351-363, 1949.

Brönnimann, S., Xoplaki, E., Casty, C., Pauling, A., and Luterbacher, J.: ENSO influence on Europe during the last centuries, Clim. Dynam., 28, 181-197, https://doi.org/10.1007/s00382006-0175-z, 2007.

Butchart, N.: The Brewer-Dobson circulation, Rev. Geophys., 52, 157-184, https://doi.org/10.1002/2013RG000448, 2014.

Butchart, N. and Scaife, A. A.: Removal of chlorofluorocarbons by increased mass exchange between the stratosphere and troposphere in a changing climate, Nature, 410, 799-802, https://doi.org/10.1038/35071047, 2001.

Butler, A. H., Polvani, L. M., and Deser, C.: Separating the stratospheric and tropospheric pathways of El Nino-Southern Oscillation teleconnections, Environ. Res. Lett., 9, 024014, http: //stacks.iop.org/1748-9326/9/i=2/a=024014, 2014.

Cagnazzo, C. and Manzini, E.: Impact of the Stratosphere on the Winter Tropospheric Teleconnections between ENSO and the North Atlantic and European Region, J. Clim., 22, 1223-1238, https://doi.org/10.1175/2008JCLI2549.1, 2009.

Cai, W., Borlace, S., Lengaigne, M., van Rensch, P., Collins, M., Vecchi, G., Timmermann, A., Santoso, A., McPhaden, M. J., Wu, L., England, M. H., Wang, G., Guilyardi, E., and Jin, F.-F.: Increasing frequency of extreme El Niño events due to greenhouse warming, Nat. Clim. Change, 4, 111-116, https://doi.org/10.1038/nclimate2100, 2014.

Calvo, N., García-Herrera, R., and Garcia, R. R.: The ENSO Signal in the Stratosphere, Annals of the New York Acad. of Sci., 1146, 16-31, https://doi.org/10.1196/annals.1446.008, 2008.
Calvo, N., Garcia, R. R., Randel, W. J., and Marsh, D. R.: Dynamical mechanism for the increase in tropical upwelling in the lowermost tropical stratosphere during warm ENSO events, J. Atmos. Sci., 67, 2331-2340, https://doi.org/10.1175/2010JAS3433.1, 2010.

Calvo-Fernandez, N., Garcia-Herrera, R., Gallego-Puyol, D., Hernandez-Martin, E., Garcia, R. R., Gimeno-Presa, L., and Ribera-Rodriguez, P.: Analysis of the ENSO Signal in Tropospheric and Stratospheric Temperatures Observed by MSU, 1979-2000, J. Clim., 17, 3934-3946, 2004.

Chandra, S., Ziemke, J. R., Schoeberl, M. R., Froidevaux, L., Read, W. G., Levelt, P. F., and Bhartia, P. K.: Effects of the 2004 El Niño on tropospheric ozone and water vapor, Geophys. Res. Lett., 34, L06802, https://doi.org/10.1029/2006GL028779, 2007.

Chandra, S., Ziemke, J. R., Duncan, B. N., Diehl, T. L., Livesey, N. J., and Froidevaux, L.: Effects of the 2006 El Niño on tropospheric ozone and carbon monoxide: implications for dynamics and biomass burning, Atmos. Chem. Phys., 9, 4239-4249, https://doi.org/10.5194/acp-9-4239-2009, 2009.

Chipperfield, M. P., Dhomse, S., Hossaini, R., Feng, W., Santee, M. L., Weber, M., Burrows, J. P., Wild, J. D., Loyola, D., and Coldewey-Egbers, M.: On the Cause of Recent Variations in Lower Stratospheric Ozone, Geophys. Res. Lett., 45, 5718-5726, https://doi.org/10.1029/2018GL078071, 2018.

Dee, D. P., Uppala, S. M., Simmons, A. J., Berrisford, P., Poli, P., Kobayashi, S., Andrae, U., Balmaseda, M. A., Balsamo, G., Bauer, P., Bechtold, P., Beljaars, A. C. M., van de Berg, L., Bidlot, J., Bormann, N., Delsol, C., Dragani, R., Fuentes, M., Geer, A. J., Haimberger, L., Healy, S. B., Hersbach, H., Hólm, E. V., Isaksen, L., Kållberg, P., Köhler, M., Matricardi, M., McNally, A. P., Monge-Sanz, B. M., Morcrette, J.-J., Park, B.-K., Peubey, C., de Rosnay, P., Tavolato, C., Thépaut, J.-N., and Vitart, F.: The ERA-Interim reanalysis: configuration and performance of the data assimilation system, Q. J. R. Meteorol. Soc., 137, 553-597, https://doi.org/10.1002/qj.828, 2011.

Dessler, A. E., Schoeberl, M. R., Wang, T., Davis, S. M., and Rosenlof, K. H.: Stratospheric water vapor feedback, P. Natl. Acad. Sci. USA, 110, 18087-18091, 2013.

Dhomse, S. S., Kinnison, D., Chipperfield, M. P., Salawitch, R. J., Cionni, I., Hegglin, M. I., Abraham, N. L., Akiyoshi, H., Archibald, A. T., Bednarz, E. M., Bekki, S., Braesicke, P., Butchart, N., Dameris, M., Deushi, M., Frith, S., Hardiman, S. C., Hassler, B., Horowitz, L. W., Hu, R.-M., Jöckel, P., Josse, B., Kirner, O., Kremser, S., Langematz, U., Lewis, J., Marchand, M., Lin, M., Mancini, E., Marécal, V., Michou, M., Morgenstern, O., O’Connor, F. M., Oman, L., Pitari, G., Plummer, D. A., Pyle, J. A., Revell, L. E., Rozanov, E., Schofield, R., Stenke, A., Stone, K., Sudo, K., Tilmes, S., Visioni, D., Yamashita, Y., and Zeng, G.: Estimates of ozone return dates from ChemistryClimate Model Initiative simulations, Atmos. Chem. Phys., 18, 8409-8438, https://doi.org/10.5194/acp-18-8409-2018, 2018.

Diallo, M., Legras, B., and Chédin, A.: Age of stratospheric air in the ERA-Interim, Atmos. Chem. Phys., 12, 12133-12154, https://doi.org/10.5194/acp-12-12133-2012, 2012.

Diallo, M., Ploeger, F., Konopka, P., Birner, T., Müller, R., Riese, M., Garny, H., Legras, B., Ray, E., Berthet, G., and Jegou, F.: Significant contributions of volcanic aerosols to decadal changes in the stratospheric circulation, Geophys. Res. Lett., 44, 1078010791, https://doi.org/10.1002/2017GL074662, 2017. 
Diallo, M., Riese, M., Birner, T., Konopka, P., Müller, R., Hegglin, M. I., Santee, M. L., Baldwin, M., Legras, B., and Ploeger, F.: Response of stratospheric water vapor and ozone to the unusual timing of El Niño and the QBO disruption in 2015-2016, Atmos. Chem. Phys., 18, 13055-13073, https://doi.org/10.5194/acp-1813055-2018, 2018.

Ern, M., Ploeger, F., Preusse, P., Gille, J. C., Gray, L. J., Kalisch, S., Mlynczak, M. G., Russell, J. M., and Riese, M.: Interaction of gravity waves with the QBO: A satellite perspective, J. Geophys. Res.-Atmos., 119, 2329-2355, https://doi.org/10.1002/2013JD020731, 2014.

Ern, M., Preusse, P., and Riese, M.: Driving of the SAO by gravity waves as observed from satellite, Ann. Geophys., 33, 483-504, https://doi.org/10.5194/angeo-33-483-2015, 2015.

Ern, M., Trinh, Q. T., Kaufmann, M., Krisch, I., Preusse, P., Ungermann, J., Zhu, Y., Gille, J. C., Mlynczak, M. G., Russell III, J. M., Schwartz, M. J., and Riese, M.: Satellite observations of middle atmosphere gravity wave absolute momentum flux and of its vertical gradient during recent stratospheric warmings, Atmos. Chem. Phys., 16, 9983-10019, https://doi.org/10.5194/acp16-9983-2016, 2016.

Field, R. D., van der Werf, G. R., Fanin, T., Fetzer, E. J., Fuller, R., Jethva, H., Levy, R., Livesey, N. J., Luo, M., Torres, O., and Worden, H. M.: Indonesian fire activity and smoke pollution in 2015 show persistent nonlinear sensitivity to El Niño-induced drought, P. Natl. Acad. Sci. USA, https://doi.org/10.1073/pnas.1524888113, 2016.

Forster, P. M. de F. and Shine, K. P.: Stratospheric water vapour changes as a possible contributor to observed stratospheric cooling, Geophys. Res. Lett., 26, 3309-3312, https://doi.org/10.1029/1999GL010487, 1999.

Forster, P. M. de F. and Shine, K. P.: Radiative forcing and temperature trends from stratospheric ozone changes, Geophys. Res. Lett., 102, 10841-10855, https://doi.org/10.1029/96JD03510, 1997.

Forster, P. M. de F. and Shine, K. P.: Assessing the climate impact of trends in stratospheric water vapor, Geophys. Res. Lett., 29, doi:10.1029/2001GL013909, 2002.

Froidevaux, L., Jiang, Y. B., Lambert, A., Livesey, N. J., Read, W. G., Waters, J. W., Browell, E. V., Hair, J. W., Avery, M. A., McGee, T. J., Twigg, L. W., Sumnicht, G. K., Jucks, K. W., Margitan, J. J., Sen, B., Stachnik, R. A., Toon, G. C., Bernath, P. F., Boone, C. D., Walker, K. A., Filipiak, M. J., Harwood, R. S., Fuller, R. A., Manney, G. L., Schwartz, M. J., Daffer, W. H., Drouin, B. J., Cofield, R. E., Cuddy, D. T., Jarnot, R. F., Knosp, B. W., Perun, V. S., Snyder, W. V., Stek, P. C., Thurstans, R. P., and Wagner, P. A.: Validation of Aura Microwave Limb Sounder stratospheric ozone measurements, J. Geophys. Res.-Atmos., 113, D15S20, https://doi.org/10.1029/2007JD008771, 2008.

Fromm, M., Tupper, A., Rosenfeld, D., Servranckx, R., and McRae, R.: Violent pyro-convective storm devastates Australia's capital and pollutes the stratosphere, Geophys. Res. Lett., 33, L05815, https://doi.org/10.1029/2005GL025161, 2006.

Fromm, M. D. and Servranckx, R.: Transport of forest fire smoke above the tropopause by supercell convection, Geophys. Res. Lett., 30, 1542, https://doi.org/10.1029/2002GL016820, 2003.

Fueglistaler, S., Dessler, A. E., Dunkerton, T. J., Folkins, I., Fu, Q., and Mote, P. W.: Tropical Tropopause Layer, Rev. Geophys., 47, G1004, https://doi.org/10.1029/2008RG000267, 2009a.
Fueglistaler, S., Legras, B., Beljaars, A., Morcrette, J.-J., Simmons, A., Tompkins, A. M., and Uppala, S.: The diabatic heat budget of the upper troposphere and lower/mid stratosphere in ECMWF reanalyses, Q. J. R. Meteorol. Soc., 135, 21-37, https://doi.org/10.1002/qj.361, 2009 b.

Fujiwara, M., Wright, J. S., Manney, G. L., Gray, L. J., Anstey, J., Birner, T., Davis, S., Gerber, E. P., Harvey, V. L., Hegglin, M. I., Homeyer, C. R., Knox, J. A., Krüger, K., Lambert, A., Long, C. S., Martineau, P., Molod, A., Monge-Sanz, B. M., Santee, M. L., Tegtmeier, S., Chabrillat, S., Tan, D. G. H., Jackson, D. R., Polavarapu, S., Compo, G. P., Dragani, R., Ebisuzaki, W., Harada, Y., Kobayashi, C., McCarty, W., Onogi, K., Pawson, S., Simmons, A., Wargan, K., Whitaker, J. S., and Zou, C.-Z.: Introduction to the SPARC Reanalysis Intercomparison Project (S-RIP) and overview of the reanalysis systems, Atmos. Chem. Phys., 17, 1417-1452, https://doi.org/10.5194/acp17-1417-2017, 2017.

Garcia-Herrera, R., Calvo, N., Garcia, R. R., and Giorgetta, M. A.: Propagation of ENSO temperature signals into the middle atmosphere: A comparison of two general circulation models and ERA-40 reanalysis data, J. Geophys. Res.-Atmos., 111, D06101, https://doi.org/10.1029/2005JD006061, 2006.

Garfinkel, C. I. and Hartmann, D. L.: Effects of the El NiñoSouthern Oscillation and the Quasi-Biennial Oscillation on polar temperatures in the stratosphere, J. Geophys. Res.-Atmos., 112, D19112, https://doi.org/10.1029/2007JD008481, 2007.

Garfinkel, C. I. and Hartmann, D. L.: Different ENSO teleconnections and their effects on the stratospheric polar vortex, J. Geophys. Res.-Atmos., 113, D18114, https://doi.org/10.1029/2008JD009920, 2008.

Garny, H., Birner, T., Bönisch, H., and Bunzel, F.: The effects of mixing on age of air, J. Geophys. Res.-Atmos., 119, 7015-7034, https://doi.org/10.1002/2013JD021417, 2014.

Hall, T. and Plumb, R. A.: Age as a diagnostic of stratospheric transport, J. Geophys. Res., 99, 1059-1070, 1994.

Hardiman, S. C., Butchart, N., and Calvo, N.: The morphology of the Brewer-Dobson circulation and its response to climate change in CMIP5 simulations, Q. J. R. Meteorol. Soc., 140, 1958-1965, https://doi.org/10.1002/qj.2258, 2014.

Haynes, P. H., McIntyre, M. E., Shepherd, T. G., Marks, C. J., and Shine, K. P.: On the "Downward Control" of Extratropical Diabatic Circulations by Eddy-Induced Mean Zonal Forces, J. Atmos. Sci., 48, 651-678, 1991.

Hegglin, M. I. and Shepherd, T. G.: Large climate-induced changes in ultraviolet index and stratosphere-to-troposphere ozone flux, Nat. Geosci., 2, 687-691, https://doi.org/10.1038/ngeo604, 2009.

Holton, J. R., Haynes, P. H., McIntyre, M. E., Douglass, A. R., Rood, R. B., and Pfister, L.: Stratospheretroposphere exchange, Rev. Geophys., 33, 403-440, https://doi.org/10.1029/95RG02097, 1995.

Iglesias-Suarez, F., Kinnison, D. E., Rap, A., Maycock, A. C., Wild, O., and Young, P. J.: Key drivers of ozone change and its radiative forcing over the 21st century, Atmos. Chem. Phys., 18, 61216139, https://doi.org/10.5194/acp-18-6121-2018, 2018.

Ineson, S. and Scaife, A. A.: The role of the stratosphere in the European climate response to El Niño, Nat. Geosci., 2, 32-36, https://doi.org/10.1038/ngeo381, 2009. 
Kawatani, Y. and Hamilton, K.: Weakened stratospheric quasibiennial oscillation driven by increased tropical mean upwelling, Nature, 497, 478-481, https://doi.org/10.1038/nature12140, 2013.

Kawatani, Y., Watanabe, S., Sato, K., Dunkerton, T. J., Miyahara, S., and Takahashi, M.: The Roles of Equatorial Trapped Waves and Internal Inertia-Gravity Waves in Driving the Quasi-Biennial Oscillation. Part I: Zonal Mean Wave Forcing, J. Atmos. Sci., 67, 963-980, https://doi.org/10.1175/2009JAS3222.1, 2010.

Khaykin, S. M., Godin-Beekmann, S., Keckhut, P., Hauchecorne, A., Jumelet, J., Vernier, J.-P., Bourassa, A., Degenstein, D. A., Rieger, L. A., Bingen, C., Vanhellemont, F., Robert, C., DeLand, M., and Bhartia, P. K.: Variability and evolution of the midlatitude stratospheric aerosol budget from 22 years of ground-based lidar and satellite observations, Atmos. Chem. Phys., 17, 18291845, https://doi.org/10.5194/acp-17-1829-2017, 2017.

Kobayashi, S., Ota, Y., Harada, Y., Ebita, A., Boriya, M., Onoda, H., Onogi, K., Kamahori, H., Endo, H., Miyaoka, K., and Takahashi, K.: The JRA-55 Reanalysis: General Specifications and Basic Characteristics, J. Meteorol. Soc. Jpn., 93, 5-48, https://doi.org/10.2151/jmsj.2015-001, 2015.

Konopka, P., Steinhorst, H.-M., Grooß, J.-U., Günther, G., Müller, R., Elkins, J., Jost, H.-J., Richard, E., Schmidt, U., Toon, G., and McKenna, D.: Mixing and ozone loss in the 1999-2000 Arctic vortex: simulations with the three-dimensional Chemical Lagrangian Model of the Stratosphere (CLaMS), J. Geophys. Res., 109, 2315, https://doi.org/10.1029/2003JD003792, 2004.

Konopka, P., Ploeger, F., Tao, M., and Riese, M.: Zonally resolved impact of ENSO on the stratospheric circulation and water vapor entry values, J. Geophys. Res.-Atmos., 121, 11486-11501, https://doi.org/10.1002/2015JD024698, 2016.

Latif, M. and Keenlyside, N. S.: El Niño/Southern Oscillation response to global warming, P. Natl. Acad. Sci. USA, 106, 2057820583, https://doi.org/10.1073/pnas.0710860105, 2009.

Laube, J. C., Newland, M. J., Hogan, C., Brenninkmeijer, C. A. M., Fraser, P. J., Martinerie, P., Oram, D. E., Reeves, C. E., Röckmann, T., Schwander, J., Witrant, E., and Sturges, W. T.: Newly detected ozone-depleting substances in the atmosphere, Nat. Geosci., 7, 266, 2014.

L'Heureux, M. L., Takahashi, K., Watkins, A. B., Barnston, A. G., Becker, E. J., Liberto, T. E. D., Gamble, F., Gottschalck, J., Halpert, M. S., Huang, B., Mosquera-Vásquez, K., and Wittenberg, A. T.: Observing and Predicting the 2015/16 El Niño, B. Am. Meteorol. Soc., 98, 1363-1382, https://doi.org/10.1175/BAMS-D-16-0009.1, 2017.

Li, F., Waugh, D. W., Douglass, A. R., Newman, P. A., Pawson, S., Stolarski, R. S., Strahan, S. E., and Nielsen, J. E.: Seasonal variations of stratospheric age spectra in the Goddard Earth Observing System Chemistry Climate Model (GEOSCCM), J. Geophys. Res., 117, D05134, https://doi.org/10.1029/2011JD016877, 2012.

Liess, S. and Geller, M. A.: On the relationship between QBO and distribution of tropical deep convection, J. Geophys. Res.Atmos., 117, D03108, https://doi.org/10.1029/2011JD016317, 2012.

Lin, P. and Fu, Q.: Changes in various branches of the Brewer-Dobson circulation from an ensemble of chemistry climate models, J. Geophys. Res.-Atmos., 118, 73-84, https://doi.org/10.1029/2012JD018813, 2013.
Livesey, N. J., Filipiak, M. J., Froidevaux, L., Read, W. G., Lambert, A., Santee, M. L., Jiang, J. H., Pumphrey, H. C., Waters, J. W., Cofield, R. E., Cuddy, D. T., Daffer, W. H., Drouin, B. J., Fuller, R. A., Jarnot, R. F., Jiang, Y. B., Knosp, B. W., Li, Q. B., Perun, V. S., Schwartz, M. J., Snyder, W. V., Stek, P. C., Thurstans, R. P., Wagner, P. A., Avery, M., Browell, E. V., Cammas, J.P., Christensen, L. E., Diskin, G. S., Gao, R.-S., Jost, H.-J., Loewenstein, M., Lopez, J. D., Nedelec, P., Osterman, G. B., Sachse, G. W., and Webster, C. R.: Validation of Aura Microwave Limb Sounder $\mathrm{O}_{3}$ and $\mathrm{CO}$ observations in the upper troposphere and lower stratosphere, J. Geophys. Res., 113, 10195-10213, https://doi.org/10.1029/2007JD008805, 2008.

Livesey, N. J., Read, W. G., Froidevaux, L., Lambert, A., Manney, G. L., Pumphrey, H. C., Santee, M. L., Schwartz, M. J., Wang, S., Cofield, R. E., Cuddy, D. T., Fuller, R. A., Jarnot, R. F., Jiang, J. H., Knosp, B. W., Stek, P. C., Wagner, P. A., and Wu, D. L.: EOS MLS Version 3.3 and 3.4 Level 2 data quality and description document, Tech. Rep., JPL JPL D-33509 Rev. C, 1-162, available at: http://mls.jpl.nasa.gov/ (last access: 9 January 2019), 2013.

Livesey, N. J., Read, W. G., Wagner, P. A., Froidevaux, L., Lambert, A., Manney, G. L., Millán Valle, L. F., Pumphrey, H. C., Santee, M. L., Schwartz, M. J., Wang, S., Fuller, R. A., Jarnot, R. F., Knosp, B. W., and Martinez, E.: Aura Microwave Limb Sounder (MLS) Version $4.2 \times$ Level 2 data quality and description document, Tech. Rep. JPL D-33509 Rev. C, 1-169, 2017.

Logan, J. A., Megretskaia, I., Nassar, R., Murray, L. T., Zhang, L., Bowman, K. W., Worden, H. M., and Luo, M.: Effects of the 2006 El Niño on tropospheric composition as revealed by data from the Tropospheric Emission Spectrometer (TES), Geophys. Res. Lett., 35, L03816, https://doi.org/10.1029/2007GL031698, 2008.

Lorenz, D. J. and DeWeaver, E. T.: Tropopause height and zonal wind response to global warming in the IPCC scenario integrations, J. Geophys. Res.-Atmos., 112, D10119, https://doi.org/10.1029/2006JD008087, 2007.

Lu, J., Chen, G., and Frierson, D. M. W.: Response of the Zonal Mean Atmospheric Circulation to El Niño versus Global Warming, J. Clim., 21, 5835-5851, https://doi.org/10.1175/2008JCLI2200.1, 2008.

Manzini, E., Giorgetta, M. A., Esch, M., Kornblueh, L., and Roeckner, E.: The Influence of Sea Surface Temperatures on the Northern Winter Stratosphere: Ensemble Simulations with the MAECHAM5 Model, J. Clim., 19, 3863-3881, https://doi.org/10.1175/JCLI3826.1, 2006.

McKenna, D., Konopka, P., Grooß, J.-U., Günther, G., Müller, R., Spang, R., Offermann, D., and Orsolini, Y.: A new Chemical Lagrangian Model of the Stratosphere (CLaMS): 1. Formulation of advection and mixing, J. Geophys. Res., 107, 4309, https://doi.org/10.029/2000JD000114, 2002.

McLandress, C. and Shepherd, T. G.: Simulated anthropogenic changes in the Brewer-Dobson Circulation, Including Its Extension to High Latitudes, J. Clim., 22, 1516, https://doi.org/10.1175/2008JCLI2679.1, 2009.

Meul, S., Langematz, U., Kröger, P., Oberländer-Hayn, S., and Jöckel, P.: Future changes in the stratosphere to troposphere ozone mass flux and the contribution from climate change and ozone recovery, Atmos. Chem. Phys., 18, 7721-7738, https://doi.org/10.5194/acp-18-7721-2018, 2018. 
Ming, A., Maycock, A. C., Hitchcock, P., and Haynes, P.: The radiative role of ozone and water vapour in the annual temperature cycle in the tropical tropopause layer, Atmos. Chem. Phys., 17, 5677-5701, https://doi.org/10.5194/acp-17-5677-2017, 2017.

Mitchell, D. M., Gray, L. J., Fujiwara, M., Hibino, T., Anstey, J. A., Ebisuzaki, W., Harada, Y., Long, C., Misios, S., Stott, P. A., and Tan, D.: Signatures of naturally induced variability in the atmosphere using multiple reanalysis datasets, Q. J. R. Meteorol. Soc., 141, 2011-2031, https://doi.org/10.1002/qj.2492, 2015.

Montzka, S., Dutton, G., Yu, P., Ray, E., Portmann, R., Daniel, J., Kuijpers, L., Hall, B., Mondeel, D., Siso, C., Nance, J., Rigby, M., Manning, A., Hu, L., Moore, F., Miller, B., and Elkins, J.: An unexpected and persistent increase in global emissions of ozone-depleting CFC-11, Nature, 557, 413-417, https://doi.org/10.1038/s41586-018-0106-2, 2018.

Nassar, R., Logan, J. A., Megretskaia, I. A., Murray, L. T., Zhang, L., and Jones, D. B. A.: Analysis of tropical tropospheric ozone, carbon monoxide, and water vapor during the 2006 El Niño using TES observations and the GEOS Chem model, J. Geophys. Res.Atmos., 114, D17304, https://doi.org/10.1029/2009JD011760, 2009.

Neu, J. L., Flury, T., Manney, G. L., Santee, M. L., Livesey, N. J., and Worden, J.: Tropospheric ozone variations governed by changes in stratospheric circulation, Nat. Geosci., 7, 340-344, https://doi.org/10.1038/ngeo2138, 2014.

Newman, P. A. and Nash, E. R.: Quantifying the wave driving of the stratosphere, J. Geophys. Res.-Atmos., 105, 12485-12497, https://doi.org/10.1029/1999JD901191, 2000.

Niwano, M., Yamazaki, K., and Shiotani, M.: Seasonal and QBO variations of ascent rate in the tropical lower stratosphere as inferred from UARS HALOE trace gas data, J. Geophys. Res., 108, 4794, https://doi.org/10.1029/2003JD003871, 4794, 2003.

Philander, S. G.: El Niño, La Nina, and the Southern Oscillation, vol. 46 of Academic Press, Cambridge Univ. Press, San Diego, CA, 1990.

Ploeger, F. and Birner, T.: Seasonal and inter-annual variability of lower stratospheric age of air spectra, Atmos. Chem. Phys., 16, 10195-10213, https://doi.org/10.5194/acp-16-101952016, 2016.

Ploeger, F., Abalos, M., Birner, T., Konopka, P., Legras, B., Müller, R., and Riese, M.: Quantifying the effects of mixing and residual circulation on trends of stratospheric mean age of air, Geophys. Res. Lett., 42, 2947-2054, https://doi.org/10.1002/2014GL062927, 2015a.

Ploeger, F., Riese, M., Haenel, F., Konopka, P., Müller, R., and Stiller, G.: Variability of stratospheric mean age of air and of the local effects of residual circulation and eddy mixing, J. Geophys. Res.-Atmos., 120, 718-733, https://doi.org/10.1002/2014JD022468, 2015b.

Plumb, R. A.: Stratospheric transport, J. Meteor. Soc. Jpn., 80, 793809, 2002.

Plumb, R. A. and Bell, R. C.: A model of the quasi-biennial oscillation on an equatorial beta-plane, Q. J. R. Meteorol. Soc., 108, 335-352, https://doi.org/10.1002/qj.49710845604, 1982.

Pommrich, R., Müller, R., Grooß, J.-U., Konopka, P., Ploeger, F., B. Vogel, M. T., Hoppe, C. M., Günther, G., Spelten, N., Hoffmann, L., Pumphrey, H.-C., Viciani, S., D’Amato, F., Volk, C. M., Hoor, P., Schlager, H., and Riese, M.: Tropical troposphere to stratosphere transport of carbon monoxide and long- lived trace species in the Chemical Lagrangian Model of the Stratosphere (CLaMS), Geosci. Model Dev., 7, 2895-2916, https://doi.org/10.5194/gmd-7-2895-2014, 2014.

Punge, H. J., Konopka, P., Giorgetta, M. A., and Müller, R.: Effect of the quasi-biennial oscillation on low-latitude transport in the stratosphere derived from trajectory calculations, J. Geophys. Res., 114, D03102, https://doi.org/10.1029/2008JD010518, 2009.

Randel, W. J., Garcia, R. R., Calvo, N., and Marsh, D.: ENSO influence on zonal mean temperature and ozone in the tropical lower stratosphere, Geophys. Res. Lett., 39, L15822, https://doi.org/10.1029/2009GL039343, 2009.

Read, W. G., Lambert, A., Bacmeister, J., Cofield, R. E., Christensen, L. E., Cuddy, D. T., Daffer, W. H., Drouin, B. J., Fetzer, E., Froidevaux, L., Fuller, R., Herman, R., Jarnot, R. F., Jiang, J. H., Jiang, Y. B., Kelly, K., Knosp, B. W., Kovalenko, L. J., Livesey, N. J., Liu, H.-C., Manney, G. L., Pickett, H. M., Pumphrey, H. C., Rosenlof, K. H., Sabounchi, X., Santee, M. L., Schwartz, M. J., Snyder, W. V., Stek, P. C., Su, H., Takacs, L. L., Thurstans, R. P., Vömel, H., Wagner, P. A., Waters, J. W., Webster, C. R., Weinstock, E. M., and Wu, D. L.: Aura Microwave Limb Sounder upper tropospheric and lower stratospheric $\mathrm{H}_{2} \mathrm{O}$ and relative humidity with respect to ice validation, J. Geophys. Res.-Atmos., 112, D24S35, https://doi.org/10.1029/2007JD008752, 2007.

Reithmeier, C., Sausen, R., and Grewe, V.: Investigating lower stratospheric model transport: Lagrangian calculations of mean age and age spectra in the GCM ECHAM4, Clim. Dynam., 30, 225-238, https://doi.org/10.1007/s00382-007-0294-1, 2008.

Riese, M., Ploeger, F., Rap, A., Vogel, B., Konopka, P., Dameris, M., and Forster, P.: Impact of uncertainties in atmospheric mixing on simulated UTLS composition and related radiative effects, J. Geophys. Res., 117, D16305, https://doi.org/10.1029/2012JD017751, 2012.

Rosenlof, K. and Holton, J.: Estimates of the stratospheric residual circulation using the downward control principle, J. Geophys. Res., 98, 10465-10479, 1993.

Santee, M. L., Manney, G. L., Livesey, N. J., Schwartz, M. J., Neu, J. L., and Read, W. G.: A comprehensive overview of the climatological composition of the Asian summer monsoon anticyclone based on 10 years of Aura Microwave Limb Sounder measurements, J. Geophys. Res.-Atmos., 122, 54915514, https://doi.org/10.1002/2016JD026408, 2017.

Sassi, F., Kinnison, D., Boville, B. A., Garcia, R. R., and Roble, R.: Effect of El Niño-Southern Oscillation on the dynamical, thermal, and chemical structure of the middle atmosphere, J. Geophys. Res.-Atmos., 109, D17108, https://doi.org/10.1029/2003JD004434, 2004.

Scaife, A. A., Comer, R., Dunstone, N., Fereday, D., Folland, C., Good, E., Gordon, M., Hermanson, L., Ineson, S., Karpechko, A., Knight, J., MacLachlan, C., Maidens, A., Peterson, K. A., Smith, D., Slingo, J., and Walker, B.: Predictability of European winter 2015/2016, Atmos. Sci. Lett., 18, 38-44, https://doi.org/10.1002/asl.721, 2017.

Schoeberl, M. R., Dessler, A. E., and Wang, T.: Simulation of stratospheric water vapor and trends using three reanalyses, Atmos. Chem. Phys., 12, 6475-6487, https://doi.org/10.5194/acp12-6475-2012, 2012. 
Simpson, I. R., Shepherd, T. G., and Sigmond, M.: Dynamics of the Lower Stratospheric Circulation Response to ENSO, J. Atmos. Sci., 68, 2537-2556, https://doi.org/10.1175/JAS-D11-05.1, 2011.

Solomon, S.: Stratospheric ozone depletion: A review of concepts and history, Rev. Geophys., 37, 275-316, https://doi.org/10.1029/1999RG900008, 1999.

Solomon, S., Rosenlof, K. H., Portmann, R. W., Daniel, J. S., Davis, S. M., Sanford, T., and Plattner, G.-K.: Contributions of Stratospheric Water Vapor to Decadal Changes in the Rate of Global Warming, Science, 327, 1219-1223, https://doi.org/10.1126/science.1182488, 2010.

Taguchi, M.: Observed connection of the stratospheric quasibiennial oscillation with El Niño-Southern Oscillation in radiosonde data, J. Geophys. Res.-Atmos., 115, D18120, https://doi.org/10.1029/2010JD014325, 2010.

Taguchi, M. and Hartmann, D. L.: Increased Occurrence of Stratospheric Sudden Warmings during El Niño as Simulated by WACCM, J. Clim., 19, 324-332, https://doi.org/10.1175/JCLI3655.1, 2006.

Thomason, L. W., Ernest, N., Millán, L., Rieger, L., Bourassa, A., Vernier, J.-P., Manney, G., Luo, B., Arfeuille, F., and Peter, T.: A global space-based stratospheric aerosol climatology: 1979-2016, Earth Sys. Sci. Data, 10, 469-492, https://doi.org/10.5194/essd-10-469-2018, 2018.

Thompson, A. M., Witte, J. C., Hudson, R. D., Guo, H., Herman, J. R., and Fujiwara, M.: Tropical Tropospheric Ozone and Biomass Burning, Science, 291, 2128-2132, https://doi.org/10.1126/science.291.5511.2128, 2001.

Timmermann, A., Oberhuber, J., Bacher, A., Esch, M., Latif, M., and Roeckner, E.: El Niño, La Nina, and the Southern Oscillation, Nature, 398, 904-905, https://doi.org/10.1038/19505, 1999.

Trentmann, J., Luderer, G., Winterrath, T., Fromm, M. D., Servranckx, R., Textor, C., Herzog, M., Graf, H.-F., and Andreae, M. O.: Modeling of biomass smoke injection into the lower stratosphere by a large forest fire (Part I): reference simulation, Atmos. Chem. Phys., 6, 5247-5260, https://doi.org/10.5194/acp6-5247-2006, 2006.

Trepte, C. R. and Hitchman, M. H.: Tropical stratospheric circulation deduced from satellite aerosol data, Nat. Geosci., 355, 626628, https://doi.org/10.1038/355626a0, 1992.

van Oldenborgh, G. J., Philip, S. Y., and Collins, M.: El Niño in a changing climate: a multi-model study, Ocean Sci., 1, 81-95, https://doi.org/10.5194/os-1-81-2005, 2005.

Vernier, J. P., Thomason, L. W., Pommereau, J. P., Bourassa, A., Pelon, J., Garnier, A., Hauchecorne, A., Trepte, C., Degenstein, D., and Vargas, F.: Major influence of tropical volcanic eruptions on the stratospheric aerosol layer during the last decade, Geophys. Res. Lett., 38, L12807, https://doi.org/10.1029/2011GL047563, 2011.

von Storch, H. and Zwiers, F. W.: Statistical analysis in climate research, Cambridge Unv. Press, 1999.

Wang, C., Deser, Y. J.-Y., DiNezio, P., and Clement, A.: El NiñoSouthern Oscillation (ENSO): A review. In Reefs of the Eastern Pacific, Springer Sci. Publish., 85-106, 2016.

Wargan, K., Orbe, C., Pawson, S., Ziemke, J. R., Oman, L. D., Olsen, M. A., Coy, L., and Emma Knowland, K.: Recent Decline in Extratropical Lower Stratospheric Ozone Attributed to Circulation Changes, Geophys. Res. Lett., 45, 5166-5176, https://doi.org/10.1029/2018GL077406, 2018.

Waters, J. W., Froidevaux, L., Harwood, R. S., Jarnot, R. F., Pickett, H. M., Read, W. G., Siegel, P. H., Cofield, R. E., Filipiak, M. J., Flower, D. A., Holden, J. R., Lau, G. K., Livesey, N. J., Manney, G. L., Pumphrey, H. C., Santee, M. L., Wu, D. L., Cuddy, D. T., Lay, R. R., Loo, M. S., Perun, V. S., Schwartz, M. J., Stek, P. C., Thurstans, R. P., Boyles, M. A., Chandra, K. M., Chavez, M. C., Chen, G.-S., Chudasama, B. V., Dodge, R., Fuller, R. A., Girard, M. A., Jiang, J. H., Jiang, Y., Knosp, B. W., LaBelle, R. C., Lam, J. C., Lee, K. A., Miller, D., Oswald, J. E., Patel, N. C., Pukala, D. M., Quintero, O., Scaff, D. M., Van Snyder, W., Tope, M. C., Wagner, P. A., and Walch, M. J.: The Earth Observing System Microwave Limb Sounder (EOS MLS) on the Aura satellite, IEEE T. Geosci. Remote, 122, 1075-1092, https://doi.org/10.1109/TGRS.2006.873771, 2006.

Waugh, D. and Hall, T.: Age of stratospheric air: Theory, observations, and models, Rev. Geophys., 40, 1010, https://doi.org/10.1029/2000RG000101, 2002.

WMO: Scientific Assessment of Ozone Depletion: 2014, Global ozone research and monitoring project - report no. 55, WMO (World Meteorological Organization), Geneva, 2014.

Wolter, K. and Timlin, M. S.: El Nino/Southern Oscillation behaviour since 1871 as diagnosed in an extended multivariate ENSO index (MEI.ext), Int. J. Climatol., 31, 1074-1087, https://doi.org/10.1002/joc.2336, 2011.

Wright, J. S. and Fueglistaler, S.: Large differences in reanalyses of diabatic heating in the tropical upper troposphere and lower stratosphere, Atmos. Chem. Phys., 13, 9565-9576, https://doi.org/10.5194/acp-13-9565-2013, 2013.

Yang, H., Chen, G., and Domeisen, D. I. V.: Sensitivities of the Lower Stratospheric Transport and Mixing to Tropical SST Heating, J. Atmos. Sci., 71, 2674-2694, https://doi.org/10.1175/JASD-13-0276.1, 2014.

Yang, H., Chen, G., Tang, Q., and Hess, P.: Quantifying isentropic stratosphere-troposphere exchange of ozone, J. Geophys. Res.-Atmos., 121, 3372-3387, https://doi.org/10.1002/2015JD024180, 2016.

Yulaeva, E. and Wallace, J. M.: The Signature of ENSO in Global Temperature and Precipitation Fields Derived from the Microwave Sounding Unit, J. Clim., 7, 1719-1736, 1994.

Zeng, G., Morgenstern, O., Braesicke, P., and Pyle, J. A.: Impact of stratospheric ozone recovery on tropospheric ozone and its budget, Geophys. Res. Lett., 37, L09805, https://doi.org/10.1029/2010GL042812, 2010.

Zhou, X., Li, J., Xie, F., Chen, Q., Ding, R., Zhang, W., and Li, Y.: Does Extreme El Niño Have a Different Effect on the Stratosphere in Boreal Winter Than Its Moderate Counterpart?, J. Geophys. Res.-Atmos., 123, 3071-3086, https://doi.org/10.1002/2017JD028064, 2018.

Zwiers, F. W. and von Storch, H.: Taking Serial Correlation into Account in Tests of the Mean, J. Clim., 8, 336-351, 1995. 